\title{
Article \\ In Situ Experimental Investigation of Slim Curtain Wall Spandrel Integrated with Vacuum Insulation Panel
}

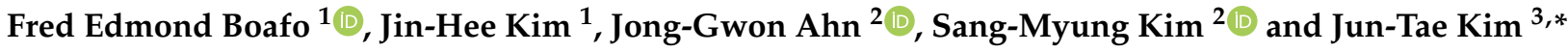 \\ 1 Green Energy Technology Research Center, Kongju National University, Cheonan 31080, Chungnam, Korea; \\ febs@smail.kongju.ac.kr (F.E.B.); jiny@kongju.ac.kr (J.-H.K.) \\ 2 Zero Energy Buildings Laboratory, Graduate School of Energy Systems Engineering, Kongju National \\ University, Cheonan 31080, Chungnam, Korea; jgsjfs@kongju.ac.kr (J.-G.A.); \\ mtanzania@smail.kongju.ac.kr (S.-M.K.) \\ 3 Department of Architectural Engineering \& Graduate School of Energy Systems Engineering, Kongju \\ National University, Cheonan 31080, Chungnam, Korea \\ * Correspondence: jtkim@kongju.ac.kr; Tel.: +82-41-521-9333
}

check for updates

Citation: Boafo, F.E.; Kim, J.-H.; Ahn, J.-G.; Kim, S.-M.; Kim, J.-T. In Situ Experimental Investigation of Slim Curtain Wall Spandrel Integrated with Vacuum Insulation Panel. Buildings 2022, 12, 199. https:// doi.org/10.3390/buildings12020199

Academic Editor: Andrea Petrella

Received: 16 December 2021

Accepted: 4 February 2022

Published: 9 February 2022

Publisher's Note: MDPI stays neutral with regard to jurisdictional claims in published maps and institutional affiliations.

Copyright: (C) 2022 by the authors. Licensee MDPI, Basel, Switzerland. This article is an open access article distributed under the terms and conditions of the Creative Commons Attribution (CC BY) license (https:// creativecommons.org/licenses/by/ $4.0 /)$

\begin{abstract}
Almost every major city's skyline is known for high-rise iconic buildings with some level of curtain wall system (CWS) installed. Although complex, a CWS can be designed for energy efficiency by integrating insulated spandrel components in space-constrained areas, such as slabs/plenums. The main aim of this study was to experimentally examine the thermal performance of an optimized curtain wall spandrel system integrated with vacuum insulation panel (VIP) as spandrel insulation. The study is based on robust experimental evaluations, augmented with appropriate numerical computations. The main study is constituted of six parts: (1) evaluation of VIP specifications and thermal properties; (2) analysis of VIP spandrel configuration, fabrication, and installation in a test building facility; (3) thermal bridge characterization of VIP spandrels; (4) monitoring and assessment of VIP durability within the spandrel cavities; (5) thermal performance analysis; and (6) assessment of related limitations and challenges, along with some further reflections. In all, $22 \mathrm{VIPs}$ (each of size $\left.600 \mathrm{~mm}^{2}\right)$ were used. The effective thermal conductivity of VIPs ranged from 5.1-5.4 $\left(10^{-3} \mathrm{~W} / \mathrm{mK}\right)$ and the average value for initial inner pressure was approximately 4.3-5.9 mbar. Three VIP spandrel cases were fabricated and tested. The results proved that the Case 3 VIP spandrel configuration (composed of a double-layer VIP) was the most improved alternative for integrating VIPs.
\end{abstract}

Keywords: vacuum insulation panel (VIP); curtain wall system (CWS); slim façade; spandrel component; experimental assessment; thermal performance

\section{Introduction}

According to the International Energy Agency (IEA), final energy use in buildings grew from 118 EJ in 2010 to around 128 EJ in 2019 [1]. Factors contributing to this rise were particularly due to energy demand for cooling, to power appliances and devices, as well as extreme weather events. Energy-related direct emissions from buildings were about $3 \mathrm{GtCO}_{2}$ in 2019, a 5\% increase since 2010. Considering indirect emissions from upstream power generation, buildings were responsible for $28 \%$ of global energy-related $\mathrm{CO}_{2}$ emissions in 2019. In absolute terms, buildings-related $\mathrm{CO}_{2}$ emissions rose and reached an all-time high of $10 \mathrm{GtCO}_{2}$ in 2019 [1]. For maintaining a comfortable indoor environment, energy-efficient building envelopes are essential, as the building envelope dominates other sections of a building system regarding the long-term impact on the ultimate energy performance throughout the lifecycle of a building [2].

At present, almost every major city's skyline is known for high-rise iconic buildings with some level of curtain wall system (CWS) installed. Curtain walled buildings appear as glistening and sleek glass façades with narrowly spaced vertical and horizontal mullions (metallic structures) overlapping with glass and spandrel panels. In the case of point-loaded 
structural glazing curtain wall systems, there are no narrow spaces between the glazing due to the absence of a metal framework. Although a curtain wall forms a barrier for a building against weather, the curtain wall itself is non-load bearing [3,4]. It is anchored from a supporting structure of a building and so hangs like a curtain [5]. Therefore, it is technically called a "curtain" wall system. Breakthroughs in the metal and glass industry, efficient prefabrication techniques, as well as advancement in curtain wall technologies, have altogether enabled construction of some of the high-rise buildings of today. Some notable advantages of curtain wall façades include daylighting improvement, smaller wall footprint and a lighter structure, faster construction time, elegant aesthetics, among others [6]. Throughout the literature, various studies have been conducted covering different aspects of curtain walls. For instance, design strategies and requirements for frameless structural glazing systems under seismic loads have been scrutinized [7]. Similarly, code provisions for seismic demands and seismic experimental tests have been reviewed [8]. Some researchers focused on delamination and failure detection in curtain wall glazing $[9,10]$. Additionally, existing safety appraisal methods for hidden-frame glass curtain walls have been evaluated and characterized into a clear five-level appraisal hierarchy system [11]. Based on numerical computations, a dynamic scheduling model for the curtain wall construction process towards improved project planning and reliability has been proposed and validated [12]. The case of fire incidents, extreme climatic conditions, and accidental or human-induced explosions in curtain walled buildings have been comprehensively assessed as well [13-15]. Concerning building energy, a sensitivity analysis on critical design parameters for CWS towards improved energy performance has been conducted [16]. Studies have claimed that curtain walls could even be a better option than masonry walls in terms of space conditioning in a Mediterranean climate, if only they were properly designed [17]. For if not carefully designed, curtain walled buildings could have higher energy requirements for space conditioning when compared to traditional concrete walls, the reasons being the high thermal conductivity difference between glass and metal components of a CWS, as well as lower thermal resistance compared to opaque walls. Consequently, converting curtain walls into plus-energy façades by integrating photovoltaic panels has been proposed and studied [18]. To improve their thermal and energy performance, curtain wall systems are integrated with insulated spandrel sections connected to glazed sections by sharing a metal frame (see Figure 1). 


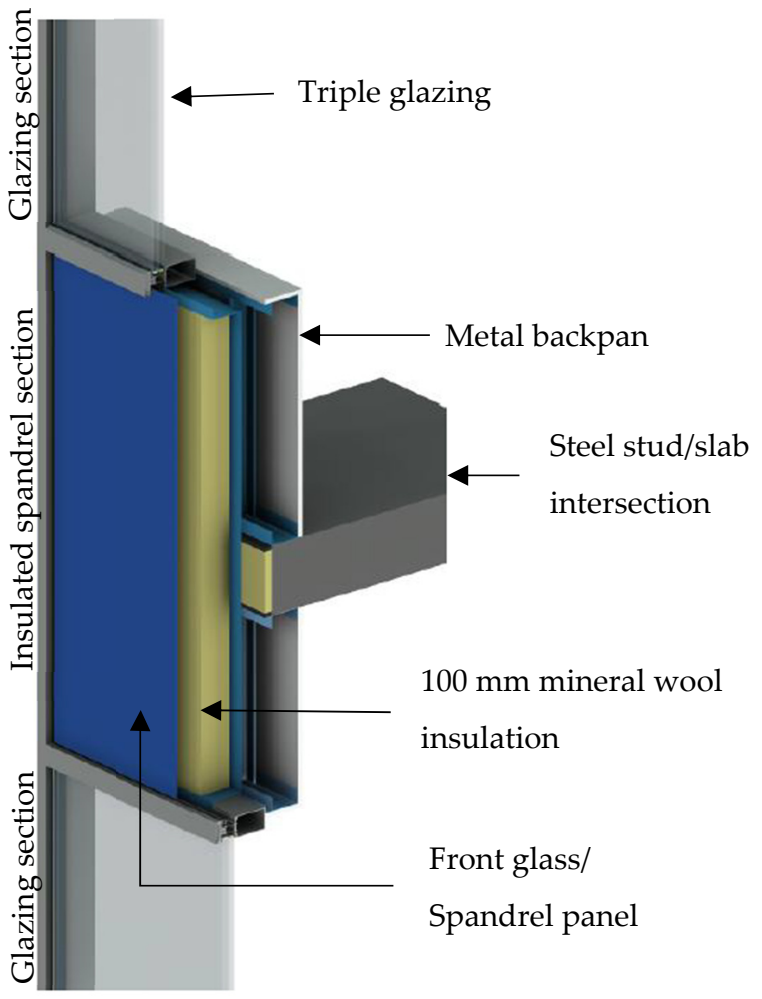

Figure 1. Curtain wall with insulated spandrel component (relabeled from Ref. [19]).

Insulated spandrel helps to curtail convective heat fluxes. The insulation also acts as a fire-stopping material at the edge of the floor slab [20]. However, topics on insulated spandrel sections are marginally considered in the literature [21,22]. Extensive studies have focused on glazing components. For instance, different modeling approaches for the glazing of curtain wall systems have been evaluated [23]. A daylighting performance analysis of glass layers for curtain walls has been investigated as well [24]. Further studies have examined an optimized approach for designing thermochromic glazing for curtain wall buildings [25]. The search for an optimal window-to-wall ratio for office buildings, considering different European climates has been studied [26]. Similarly, the impact of various ratios of glazing-to-external wall areas on energy use in office buildings has been evaluated [27]. Towards controlling solar gains and assessing visual comfort, a sensitivity analysis was performed considering single office units fitted with metal mesh as shading devices [28]. Due to safety concerns, a robot prototype with dual suction cups for cleaning the glazing of high-rise glass curtain walls has been developed and tested [29]. A stateof-the-art review and assessment of future possibilities for fenestration products have been conducted [30]. Likewise, some researchers have carried out a systematic review on the balance between the thermal and daylighting performance of glazing systems and related effects on indoor comfort and energy use [31], and developments in glazing technologies and applications have been comprehensively studied [32]. In addition, a review on aerogel glazing systems for building applications focusing on the fabrication process, thermal, optical, and acoustic properties, quality of lighting, and energy savings compared to conventional glazing systems have been investigated [33]. Even so, there are some challenges to adequately insulating spandrel sections of such slim curtain wall façades to satisfy building energy codes.

Firstly, depending on the configuration of a spandrel, about $15-25 \mathrm{~cm}$ of traditional insulation material may be required to fulfill prevailing building energy regulations [34]. For instance, the typical curtain wall shown in Figure 1 utilized $100 \mathrm{~mm}$ thick mineral wool insulation. Even with a thermally broken aluminum frame and a triple glazing system, center-of-glazing and spandrel $U$-values of $1 \mathrm{~W} / \mathrm{m}^{2} \mathrm{~K}$ and $0.89 \mathrm{~W} / \mathrm{m}^{2} \mathrm{~K}$ were estimated 
for the system, respectively [20], which were very far from the requirements defined in energy codes like ASHRAE 90.1. Generally, most opaque insulated spandrels do not satisfy the prescriptive insulation values or effective $U$-values for cold climates [35]. Secondly, to maintain aesthetics, insulated spandrels are commonly installed as separation elements between floors (at slab/plenum areas) only. This restriction has a direct consequence on the window-to-wall ratio, as well as design flexibility. It is worth noting that besides visible protrusions, usable indoor space is significantly reduced when a thick insulated spandrel section is extended beyond slab and plenum areas. Additionally, to make space for such thick traditional insulation materials, longer inner length and thicker back panels are used. Specifically, the inner length of curtain wall frame relates to its structural performance. Based on structural specifications, the inner length can be shortened. In that case, there may not be enough space to install the required thickness of insulation. Due to this space limitation, even when high structural performance is not needed, the inner length is still enlarged to accommodate the required thickness of insulation. Owing to the aforementioned challenges, a thin and super-insulating material solution is crucially needed. Alternatively, vacuum insulation panels (VIP) are a viable means of insulation for curtain wall spandrels due to VIPs' high thermal resistance per unit thickness compared to any other kind of insulation currently available [36-43]. Basically, VIP is composed of a micro-/nano-porous core material seal under vacuum in a gas-tight laminate envelope. Consequently, to achieve the same $U$-value, the equivalent thickness of VIP required is extremely reduced as compared to other traditional insulation materials. This makes VIP exceptionally useful for space-tight applications. Figure 2 compares details for a curtain wall insulated with a spandrel section with traditional insulation material and a VIP. It can be seen from Figure 2 (left) that an enlarged inner length is indeed needed to accommodate traditional insulation. Conversely, Figure 2 (right) depicts a plausible shorter inner length for the spandrel insulated with VIP. Particularly for curtain wall applications, one of the relatively overlooked but significantly important characteristics of VIP is its non-flammability according to European standards [44].
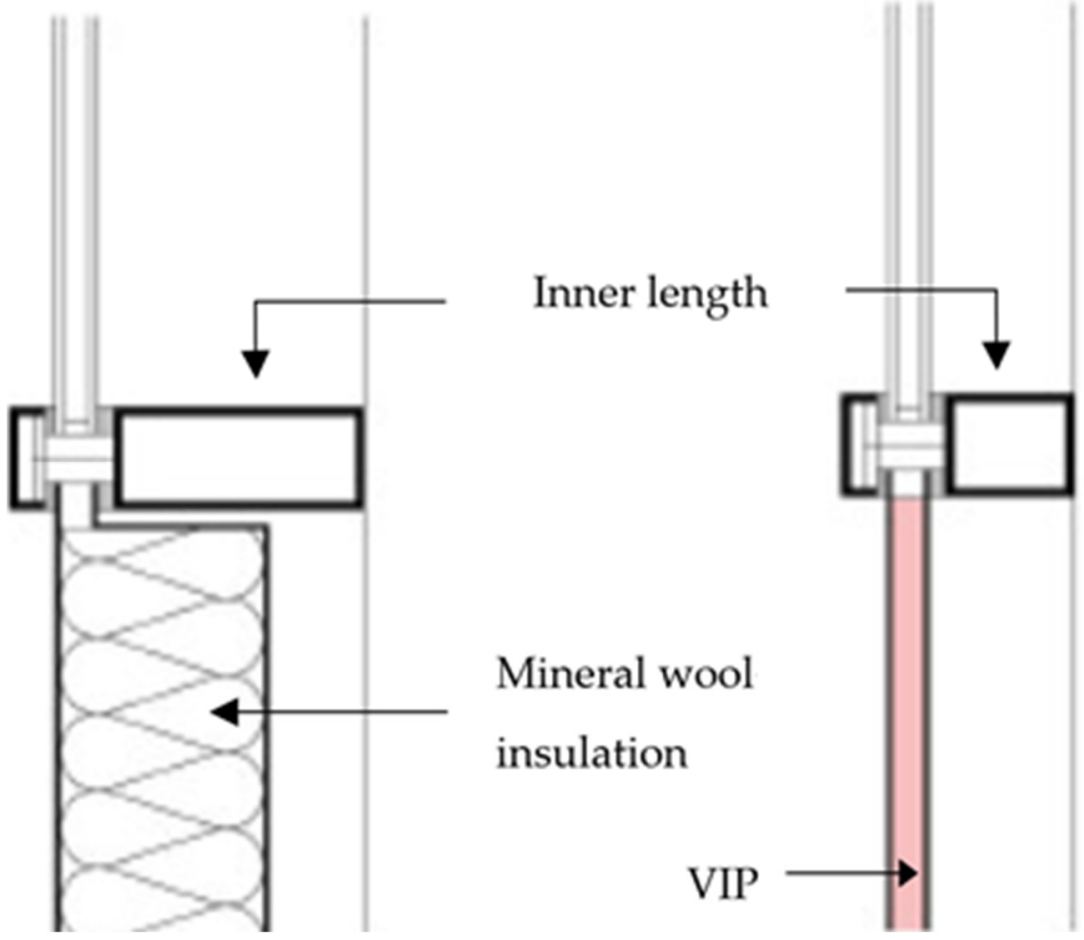

Figure 2. Schematic of curtain wall spandrel insulated with traditional insulation (left) and VIP (right). 
Based on numerical computations, annual energy use for a five-story curtain walled building has been investigated [19]. Three spandrel insulation alternatives (VIP alone, mineral wool alone, and VIP coupled with mineral wool) and four representative locations in the USA (Detroit, St Louis, Phoenix) and Canada (Winnipeg) were considered in the study. The results showed that VIP spandrel types had the least total energy (heating and cooling) usage. Particularly for colder climates (except for Phoenix), a CWS composed of a VIP spandrel coupled with a double-glazing system used less energy (about 17,877-43,668 kWh/yr) for space conditioning compared to a mineral wool spandrel coupled with a triple glazing system. Using an accelerated aging approach, thermal conductivity evolution of VIPs integrated in the cavity of an insulation glass unit (IGU) were monitored [45]. The VIP-IGU assembly was referred to as an architectural insulation module (AIM). The principal use for the AIM assembly was for curtain wall applications either as insulated spandrels (as separation elements between floors) or as non-vision panels (due to inherent slimness) to be used alongside vision panels. VIPs $20 \mathrm{~mm}$ in thickness were used for AIMs made of fumed silica core material enclosed in a metalized envelope. The dimensions of the VIP and AIM were $250 \mathrm{~mm} \times 250 \mathrm{~mm}$ and $300 \mathrm{~mm} \times 300 \mathrm{~mm}$, respectively. AIMs were monitored for more than 20 weeks under severe cycling temperature $\left(-20^{\circ} \mathrm{C}\right.$ to $\left.80^{\circ} \mathrm{C}\right)$ and humidity $(10 \%$ to $90 \%)$ conditions in a climatic chamber. The results proved that the protection factor for the VIP used within the AIM was more than ten times that of the unprotected VIP. The AIM concept is a strategy to guarantee the durability of VIPs as well as extend VIPs' service life in curtain walled buildings. Realistically, except for some peculiar cases, VIPs are not expected to encounter such harsh aging conditions in real building applications. A comprehensive review covering the thermal and energy performance of curtain walls, the development and building applications of VIPs, and opaque curtain wall spandrels insulated with VIPs has been conducted recently [46]. Researchers concluded that VIP technology is a leap forward in thermal insulation for building applications, especially slim façades, such as curtain walls. Some specific suggestions were that VIP spandrels could be designed such that non-destructive examinations like infrared thermography can be conducted on-site. In addition, the need for commercialization efforts for some VIP technological developments to end up in off-the-shelf standardized VIPs and curtain wall components was highlighted. Nevertheless, it was found that proper long-term monitored assessments of curtain wall installations with VIP spandrels are lacking in the literature. To that end, then, this study was designed.

This study is part of a project that was commissioned to propose, develop, and examine the thermo-energy performance of curtain wall spandrels insulated with vacuum insulation panels (CWS-VIP sp.). Based on numerical and analytical procedures, Part 1 of the project focused on the concept and governing heat transfer equations, initial VIP spandrel models and validation, the curtain wall vision-spandrel ratio effect on building energy, the effect of 2D/3D thermal bridges, and overall thermal performance for curtain walls with and without insulated spandrels (already published in Ref. [34]). The aim of Part 2 was to experimentally examine the dynamic thermal performance of an optimized curtain wall spandrel system integrated with a VIP as spandrel insulation. This paper focusses on Part 2. To that effect, this study is based on robust experimental evaluations carried out over 1.5 years, augmented with appropriate numerical computations. Specifically, three alternative VIP spandrel configurations geared towards minimizing thermal bridges and improving insulation performance while safeguarding the durability of VIPs were critically examined. Infra-red thermography assessments and temperature monitoring campaigns showed that VIPs had been properly integrated in the system, with no defects or failure. Overall, the results proved that the Case 3 VIP spandrel configuration (which was composed of a double-layer VIP structure) was the most improved alternative for integrating VIPs, despite complexities related to its fabrication. Finally, noteworthy limitations of experimental methods employed and future perspectives are duly discussed. 


\section{Materials and Methods}

In this section, detailed experimental procedures and the numerical evaluations used in this study are presented. The section commences by reporting material specifications and in lab assessments of individual VIPs. Then, numerical simulations (using experimental data from in lab tests as inputs) towards evaluating thermal characteristics of VIP spandrels are explained. Afterwards, procedures for the fabrication of VIP spandrel components and installation of the spandrel units in a real-scale mockup building facility are described. Lastly, monitoring methods are reported.

\subsection{Specifications and in Lab Assessment of VIP Properties}

All VIPs used in this study are commercial grade materials provided by a leading Korean VIP manufacturer. The VIPs were made of fumed silica core material encapsulated in a metalized laminate envelope material. The laminate was composed of three metalized polyethylene terephthalate (PET) films with low-density polyethylene (LDPE) as a sealing layer, laminated together using polyurethane (PU) glue. PET serves as an excellent flat substrate for the metalized aluminum (AL) barrier. Thin Al barrier layers restrict gas and moisture permeation into the core material. LDPE is used for sealing the weld seam joints of the panel. A schematic representation and SEM of the laminate's structure are shown in Figure ??a,b, respectively. In addition, specifications of the metalized laminate material provided by the envelope manufacturer are listed in Table 1.

\begin{tabular}{|c|c|}
\hline PET & Polyethylene terepthalate $(12 \mu \mathrm{m})$ \\
\hline $8 \% \mathrm{AL}$ & Aluminum $(0.1 \mu \mathrm{m})$ \\
\hline PU & Polyurethane glue $(2 \mu \mathrm{m})$ \\
\hline PET & Polyethylene terephthalate $(12 \mu \mathrm{m})$ \\
\hline AL 89808 & Aluminum $(0.1 \mu \mathrm{m})$ \\
\hline PU & Polyurethane glue $(2 \mu \mathrm{m})$ \\
\hline PET & Polyethylene terephthalate $(12 \mu \mathrm{m})$ \\
\hline AL 89898 & Aluminum $(0.1 \mu \mathrm{m})$ \\
\hline PU & Polyurethane glue $(2 \mu \mathrm{m})$ \\
\hline LDPE & Low density polyethylene $(50 \mu \mathrm{m})$ \\
\hline
\end{tabular}

Figure 3. Cont. 


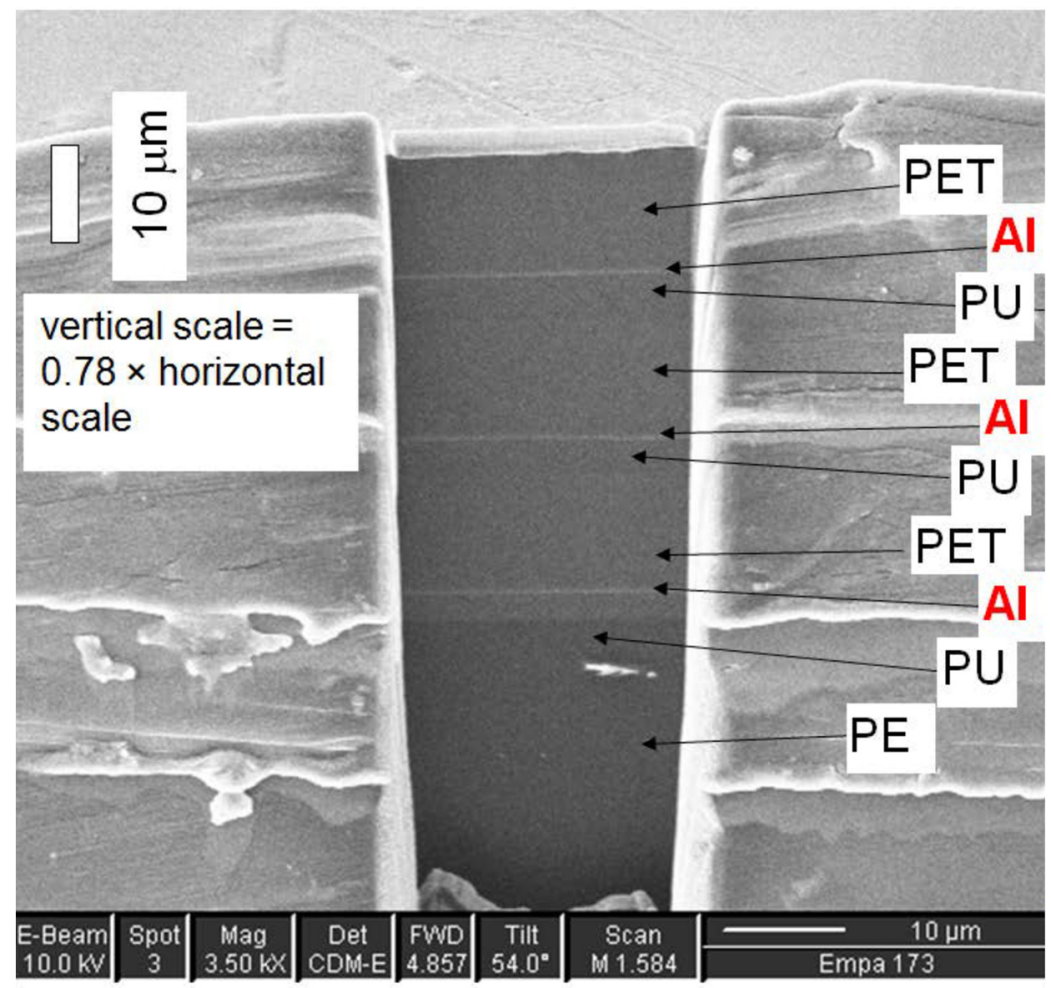

(b)

Figure 3. Details of tri-metalized laminate envelope. (a) Structure of laminate; (b) SEM micrograph [47].

Table 1. Properties of metalized envelope material [48].

\begin{tabular}{ccc}
\hline Property & Test Method/Condition & Index \\
\hline Total thickness & & $92(\mu \mathrm{m})$ \\
Heat seal strength (HSS) & $165{ }^{\circ} \mathrm{C}, 4 \mathrm{~kg} / \mathrm{cm}^{2}, 2 \mathrm{~s}$ & $>3.5(\mathrm{~N} / \mathrm{mm})$ \\
Puncture resistance (PR) & FTMS $101 \mathrm{C} 2065$ & $130(\mathrm{~N})$ \\
Moisture vapor transmission rate (MVTR) & ASTM F-1249-90, 38 ${ }^{\circ} \mathrm{C} 90 \% \mathrm{RH}$ & $<0.015\left(\mathrm{gr} / \mathrm{m}^{2} \mathrm{day}\right)$ \\
Gas Transmission Rate (GTR) & $22{ }^{\circ} \mathrm{C} 50 \% \mathrm{RH}$ & $<9\left(\mathrm{cc}(\mathrm{STP}) / \mathrm{m}^{2} /\right.$ year $)$ \\
\hline
\end{tabular}

The inner pressure state of the VIPs was evaluated using a custom-made apparatus which operates based on pressure compensation (also called the envelope foil lift-off method). The apparatus was developed in accordance with IEA EBC Annex 39 guidelines [36]. The foil lift-off method operates on a pressure equilibrium between the internal and external environment of a panel. Figure 4 depicts details of the inner pressure measuring equipment. For the custom-made apparatus, the vacuum chamber can accommodate a maximum sample size of $1 \mathrm{~m} \times 1 \mathrm{~m}$ and has a minimum degree-of-vacuum up to 0.001 Torr $(0.13 \mathrm{~Pa})$. The vacuum chamber, with an error rate of $0.1 \%$, was equipped with a highprecision laser sensor capable of detecting changes on a millimeter scale. In the vacuum chamber, the laser sensor had a measuring distance of $130 \mathrm{~mm}$, a range of $\pm 15 \mathrm{~mm}$ to $\pm 12 \mathrm{~mm}$, and an accuracy of $\pm 0.1 \%$ to $\pm 0.25 \%$ [49]. 


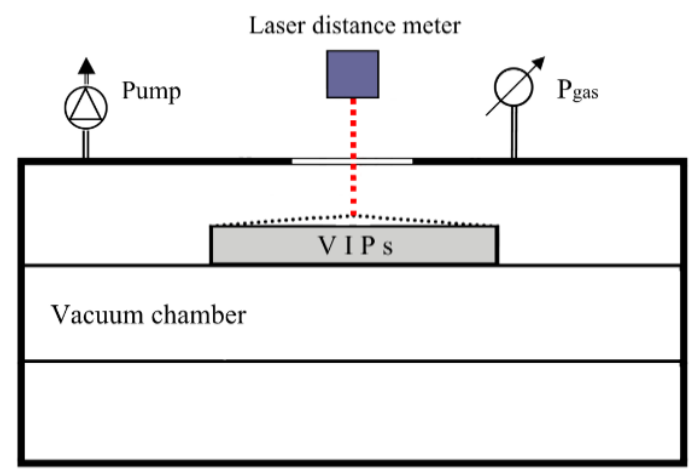

(a)

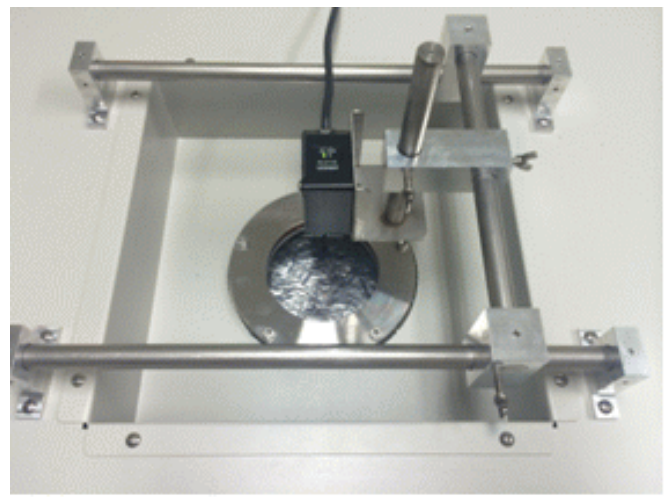

(b)

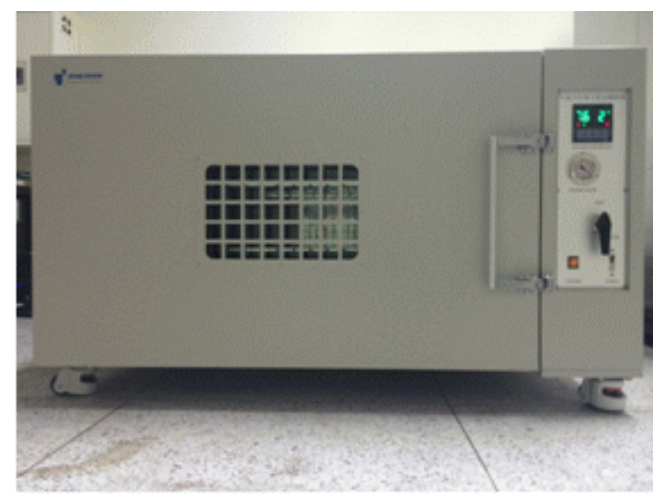

(c)

Figure 4. VIP inner pressure measurement apparatus: (a) concept, (b) laser component, and (c) vacuum chamber [49].

Thermal conductivity measurements were carried out using heat flow meter instrumentation (EKO HC-074) at a hot plate temperature of $38^{\circ} \mathrm{C}$ and a cold plate temperature of $10{ }^{\circ} \mathrm{C}$, under room conditions (temperature of $21-23{ }^{\circ} \mathrm{C}$ and relative humidity of $50-55 \%$ ). The heat flow meter is accurate with a manufacturer's specified repeatability of $0.2 \%$ and reproducibility of $0.5 \%$.

\subsection{Initial Numerical Computations}

Based on Physibel BISCO/TRISCO computations, Part 1 of this project mainly investigated overall thermal performance for curtain walls with and without insulated spandrels, considering different levels of thermal bridges [34]. Thus, these subjects are not considered in the present study. However, models developed in Part 1 were fine-tuned according to the actual components and material specifications of VIP spandrels to be used for mockup tests later in this study. For instance, experimental data for VIPs and extruded polystyrene (XPS) 
obtained from laboratory tests were used as inputs for computations. In addition, structural features of a thermally broken aluminum frame system to be used for mockup experiments was modeled. BISCO and TRISCO are thermal analysis programs developed by Physibel for steady state heat transfer with $2 \mathrm{D}$ and $3 \mathrm{D}$ objects consisting of different materials and submitted to different boundary conditions, using the finite difference method [50,51]. Numerous researchers $[37,52-58]$ have employed BISCO and TRISCO to investigate various thermal performance aspects of VIP components and building systems with VIP, proving that BISCO and TRISCO are sufficiently reliable tools for the analysis of VIP components and constructions with VIP. Prior to experimental assessments, alternative VIP spandrel configurations aimed at: (i) reducing thermal bridges of the overall spandrel system, (ii) protecting the durability of VIPs integrated in the spandrel system, (iii) enhancing the ease of fabrication, and (iv) using readily available materials that were proposed, the thermal performance of which was scrutinized. Since the aim of this study concerns the spandrel section of curtain wall systems, the modeling decoupled (separated) the vision section from the spandrel section. In this study, the VIP was modeled with the effective thermal conductivity value. The effective thermal conductivity accounts for thermal bridging due to the multilayered laminate envelope and core material, panel size, linear thermal transmittance, and VIP weld seam design at the edge of the panel. This approach was already used in other studies $[53,59,60]$. To model very thin laminate layers with thicknesses in the range of $0.1 \mu \mathrm{m}-50 \mu \mathrm{m}$ (for the case of the VIPs used in this study) is very difficult and even requires more sophisticated numerical software. In addition, modeling all envelope material layers separately would require very dense grids [58], and the spandrel scenarios in this study were modeled under the same conditions, so no significant variation in results is attributed to using the effective thermal conductivity value. In all, three VIP spandrel configurations were considered, and their details will be presented in the following Section 2.3. The thermophysical properties of material components of the spandrel system and boundary conditions for numerical simulations, in compliance with the Korean Building Energy Code [61], are summarized in Tables 2 and 3, respectively.

Table 2. Thermal and physical properties of material components for VIP spandrels.

\begin{tabular}{|c|c|c|c|c|}
\hline Material & Function & $\begin{array}{l}\text { Thermal Conductivity, } \\
\text { W/mK }\end{array}$ & $\begin{array}{l}\text { Density, } \\
\mathrm{kg} / \mathrm{m}^{3}\end{array}$ & $\begin{array}{l}\text { Specific Heat, } \\
\mathrm{J} /(\mathrm{kgK})\end{array}$ \\
\hline Aluminum ${ }^{1}$ & Frame & 160 & 2800 & 880 \\
\hline Glass $^{1}$ & Structural panel & 1 & 2500 & 750 \\
\hline Reinforced polyamide $^{1}$ & Primary seal & 0.3 & 1450 & 1600 \\
\hline Silicone ${ }^{1}$ & Secondary seal & 0.35 & 1200 & 1000 \\
\hline EPDM $^{1}$ & Gasket & 0.25 & 1150 & 1000 \\
\hline Silica gel ${ }^{1}$ & Desiccant & 0.13 & 720 & 1000 \\
\hline $\mathrm{XPS}^{2}$ & Thermal breaker & 0.028 & 30 & 1000 \\
\hline VIP $(10 \mathrm{~mm})^{2,3}$ & Spandrel insulation & 0.0051 & 200 & 800 \\
\hline $\operatorname{VIP}(15 \mathrm{~mm})^{2,3}$ & Spandrel insulation & 0.0051 & 200 & 800 \\
\hline $\operatorname{VIP}(25 \mathrm{~mm})^{2,3}$ & Spandrel insulation & 0.0054 & 200 & 800 \\
\hline
\end{tabular}

${ }^{1}$ ISO 10456 [62]. ${ }^{2}$ Based on in lab experimental tests. ${ }^{3}$ Effective thermal conductivity values.

Table 3. Boundary conditions.

\begin{tabular}{ccc}
\hline Environment & Temperature $\left({ }^{\circ} \mathbf{C}\right)$ & $\begin{array}{c}\text { Surface Heat Transfer Coefficient } \\
\left(\mathbf{W} / \mathbf{m}^{\mathbf{2}} \mathbf{K}\right)\end{array}$ \\
\hline Exterior & -11.3 & 23.25 \\
Interior & 20 & 9.09 \\
\hline
\end{tabular}




\subsection{Outdoor Mock-Up Experimental Assessments}

\subsubsection{VIP Spandrel Configurations}

The baseline model (Case 1) was composed of single-layer $25 \mathrm{~mm}$ thick VIP integrated between two $6 \mathrm{~mm}$ glass panes, as depicted in Figure 5a. The total thickness of the baseline case was $37 \mathrm{~mm}$. Details of Case 2 are shown in Figure 5b. The main difference between Case 2 and Case 1 was the use of a $5 \mathrm{~mm}$ layer of XPS between the outer glass pane and the exterior face of the one-layer $25 \mathrm{~mm}$ thick VIP. The total thickness of Case 2 was $42 \mathrm{~mm}$. It is worth noting that both Case 1 and Case 2 have a single-layer VIP. Application of single-layer VIP is quite common in building constructions [53,60,63-66]. Finally, Case 3 was made up of a double-layer VIP of thickness $10 \mathrm{~mm}$ (towards outdoors) and $15 \mathrm{~mm}$ (towards indoors), with a $5 \mathrm{~mm}$ layer of XPS between the adjacent surfaces of the VIPs. Case 3 is represented by Figure 5c. The total thickness of Case 3 was $47 \mathrm{~mm}$. Case 3 was designed in this particular manner to evaluate the effect of utilizing two staggered VIPs of equivalent total thickness of $25 \mathrm{~mm}$ (the same as the VIP thickness for Case 1 and Case 2) as compared to using a one-layer VIP. Double-layer VIP design has been applied in such applications as precast concrete integrated with VIPs [67] and low-sloped commercial roofing systems [68]. Since the study concerned the spandrels of a curtain wall, experiments were carried out on spandrel specimens only, to better understand their thermal behavior. A typical thermally broken aluminum framing system $\left(U\right.$-value of $\left.2.7 \mathrm{~W} / \mathrm{m}^{2} \mathrm{~K}\right)$ was used to support the spandrel components, which was suitable for the purpose of the study. It is worth noting that the configurations of VIP spandrels in Figure 5 are the same for the VIP spandrels modeled under Section 2.2, except for the inclusion of an ultraviolet (UV) control film. This is to protect the surface of a VIP facing outdoors from direct solar radiation. Table 4 summarizes the properties of the UV film.

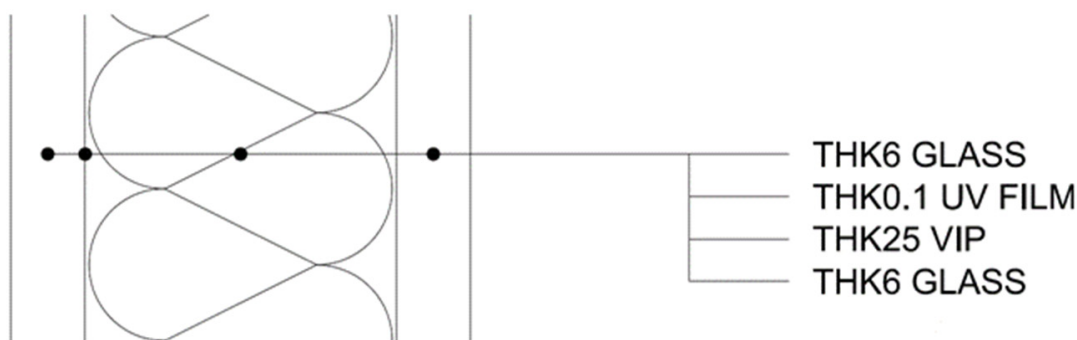

(a)

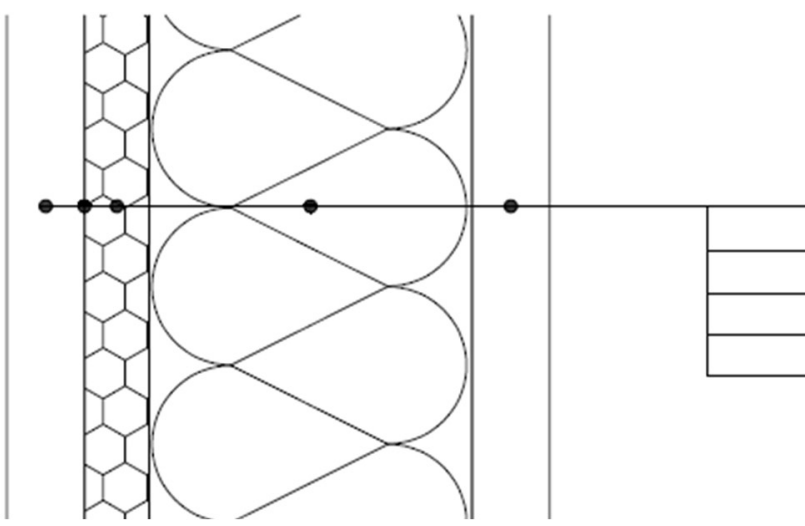

THK6 GLASS

THK0.1 UV FILM

THK5 XPS

THK25 VIP

THK6 GLASS

(b)

Figure 5. Cont. 


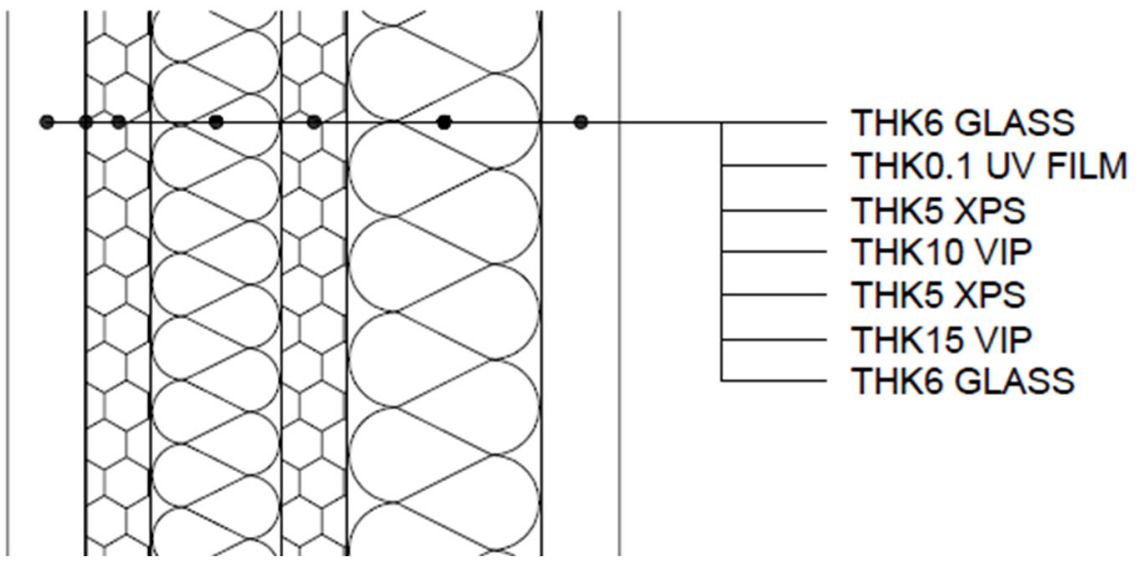

(c)

Figure 5. Cross-sectional details of VIP spandrel cases. (a) Case 1; (b) Case 2; (c) Case 3.

Table 4. Properties of UV control film [69].

\begin{tabular}{cc}
\hline Property & Index \\
\hline Solar heat gain coefficient (SHGC) & 0.23 \\
U value & 0.93 \\
Total solar energy rejected & $77 \%$ \\
\hline
\end{tabular}

\subsubsection{Overview of Real-Scale Mockup Building Facility}

Details of the mockup test building facility used for experimental investigations are shown in Figure 6.
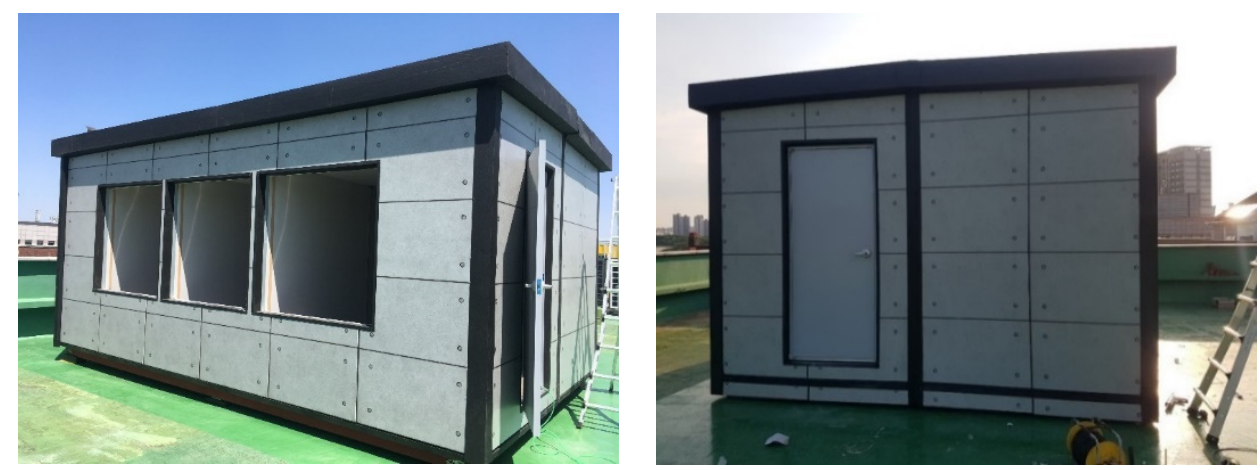

Figure 6. Photographs of the mockup test building facility.

The test facility, measuring $6 \mathrm{~m}$ (length) by $4 \mathrm{~m}$ (width) by $2.7 \mathrm{~m}$ (height), is located at the College of Engineering Campus of Kongju National University, in Cheonan. To avoid shade and to be exposed to solar radiation, the mockup facility was mounted on the rooftop of a four-story educational building. The exterior walls of the test facility, from outdoors to indoors, were composed of a sandwich panel (painted metal sheet, $100 \mathrm{~mm}$ EPS insulation and painted metal sheet), $50 \mathrm{~mm}$ glass wool insulation, and a $19 \mathrm{~mm}$ two-ply gypsum board. The south-facing façade of the facility was designed with openings measuring $1360 \mathrm{~mm} \times 1360 \mathrm{~mm}$ (with tolerance of $\pm 5 \mathrm{~mm}$ ) into which VIP spandrel components could be installed. The floor plan of the test building is shown in Figure 7 . 


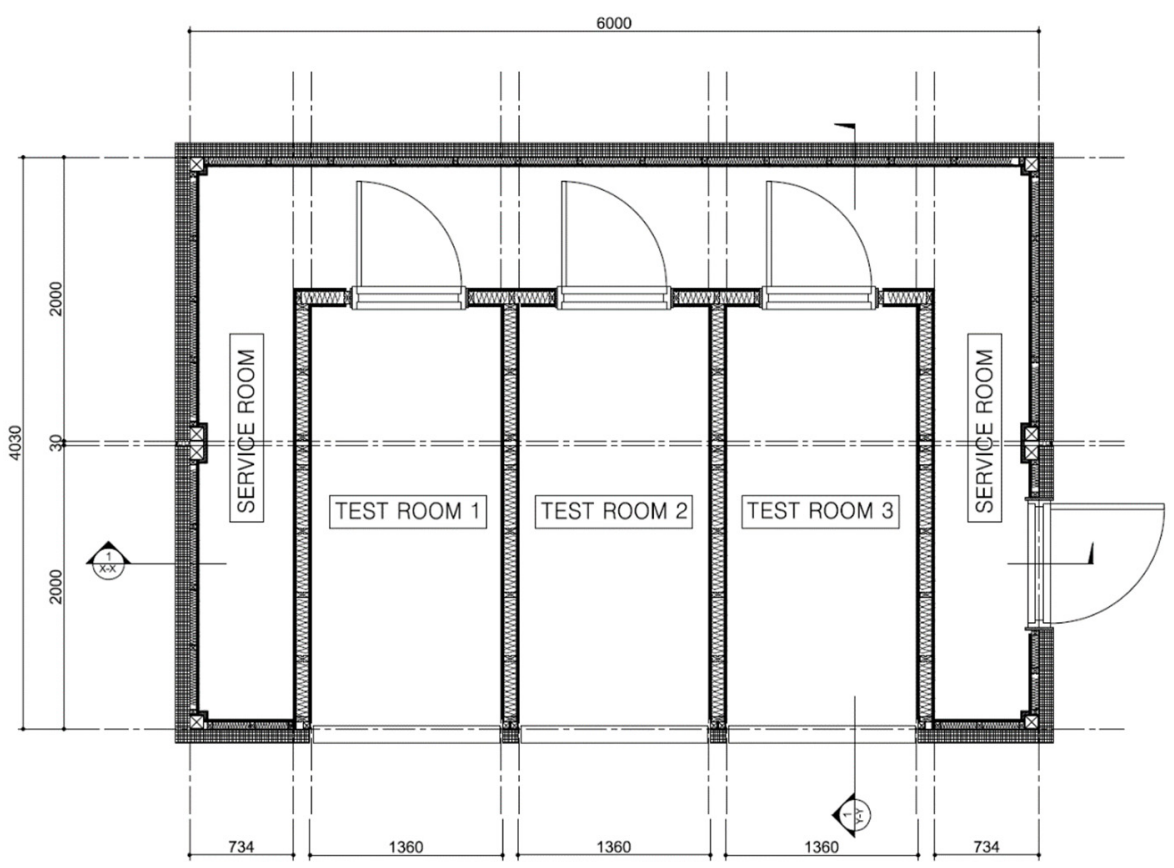

Figure 7. Plan of test building facility (units: $\mathrm{mm}$ ).

Interior partitions of the test facility consisted of $19 \mathrm{~mm}$ two-ply gypsum board, $90 \mathrm{~mm}$ glass wool insulation and $19 \mathrm{~mm}$ two-ply gypsum board. The indoor temperatures in both test and service rooms were controlled by an electric heat pump (EHP) air conditioning system. The system can operate in cooling mode only. The facility was designed to have three test rooms and was fabricated in a manner to ensure that the test rooms were exposed to the same outdoor and indoor environmental conditions.

\subsubsection{Spandrel Fabrication, Installation, and Monitoring Systems}

All materials used for the mockup tests are commercially available products. The VIP spandrel fabrication was carried out in coordinated sequences on site. Depending on the configuration of the spandrel, the sandwich panels were duly constructed. Spandrel integrated VIP components were then installed in the test building facility. The internal and external surface temperatures of the spandrel specimens, as well as VIP surface temperatures inside the spandrel cavity, were monitored using K-Type thermocouples. The tips of the thermocouples' wire legs were spot welded with a thermocouple welder prior to setting up in the test building. This was to create a junction where temperature could be measured and to prevent short circuiting. To avoid measurement errors, thermocouples were calibrated and tested before installation in the mockup facility. Global solar radiation incident on the vertical surface was measured using a pyranometer, and outdoor temperature and humidity profiles were measured with a temperature and relative humidity transmitter. The inductive head of the humidity transmitter was shielded from solar radiation to reduce the influence of direct solar radiation on measurements. The indoor climatic environment for individual tests and service rooms were monitored as well. Data was recorded at intervals of $5 \mathrm{~min}$. The durability of VIPs and the thermal bridge of the overall system were examined by infra-red thermography. Details and technical and uncertainty specifications of test equipment used for monitoring are listed in Table 5. Actual images of the experimental apparatus are shown in Figure 8. In all, 26 temperature sensors were used to measure surface and cavity temperatures. Table 6 summarizes the number of sensors used per case. Figure 9 shows thermocouple positions for the interior and exterior surfaces of spandrels, while Figure 10 displays thermocouple positions at the VIP surfaces inside the spandrel cavity. The final building with the spandrel specimens installed is presented in Figure 11. 
Table 5. Specification and measurement accuracy of measuring equipment.

\begin{tabular}{|c|c|}
\hline Equipment Type (Model) & Specifications \\
\hline $\begin{array}{l}\text { K-Type thermocouple } \\
\text { (KX-F-0.32) }\end{array}$ & $\begin{array}{l}\text { Measurement range: }-200{ }^{\circ} \mathrm{C} \text { to } 1372{ }^{\circ} \mathrm{C} \\
\text { Accuracy: } \pm 0.50 \text { (at }-200{ }^{\circ} \mathrm{C} \text { to }-50{ }^{\circ} \mathrm{C} \text { ), } \\
\quad \pm 0.25 \text { (at }-50{ }^{\circ} \mathrm{C} \text { to } 1372{ }^{\circ} \mathrm{C} \text { ) }\end{array}$ \\
\hline $\begin{array}{l}\text { Data logger for thermocouple calibration } \\
\text { (Graphtec GL800) }\end{array}$ & $\begin{array}{l}\left.\text { Clock accuracy: } \pm 0.002 \% \text { (ambient temperature } 23^{\circ} \mathrm{C}\right) \\
\text { Operating environment: } 0{ }^{\circ} \mathrm{C} \text { to } 45{ }^{\circ} \mathrm{C} / 5 \% \mathrm{RH} \text { to } 85 \% \mathrm{RH} \\
\text { Measurement range and accuracy: } \pm\left(0.05 \% \text { of reading }+2{ }^{\circ} \mathrm{C}\right) \text { at }-200{ }^{\circ} \mathrm{C} \\
\text { to }-100{ }^{\circ} \mathrm{C} ; \pm\left(0.05 \% \text { of reading }+1{ }^{\circ} \mathrm{C}\right) \text { at }-100{ }^{\circ} \mathrm{C} \text { to } 1370{ }^{\circ} \mathrm{C} \text {. }\end{array}$ \\
\hline $\begin{array}{l}\text { Thermocouple welder } \\
\text { (DK-50) }\end{array}$ & $\begin{array}{c}\text { Input voltage: } 220 \mathrm{~V} \mathrm{AC} 1 \mathrm{~A} 60 \mathrm{~Hz} \\
\text { Output voltage: } 24-48 \mathrm{VDC}(20,000 \mathrm{uF})\end{array}$ \\
\hline $\begin{array}{l}\text { Pyranometer } \\
\text { (EKO MS-402) }\end{array}$ & $\begin{array}{c}\text { Operating temperature: }-40{ }^{\circ} \mathrm{C} \text { to } 80{ }^{\circ} \mathrm{C} \\
\text { Irradiance range: } 0 \text { to } 4000 \mathrm{Wm}^{-2} \\
\text { Wavelength range: } 285-3000 \mathrm{~nm} \\
\text { Response time } 95 \%:<8 \mathrm{~s} \\
\text { Sensitivity: } 7 \mu \mathrm{V} / \mathrm{Wm}^{-2} \\
\text { Temperature response }-10^{\circ} \mathrm{C} \text { to } 40: \pm 1 \% \\
\text { Accuracy: first class pyranometer according to ISO } 9060\end{array}$ \\
\hline $\begin{array}{l}\text { Indoor air temperature and relative humidity } \\
\text { transmitter (EE160) }\end{array}$ & $\begin{array}{l}\text { Operating temperature: }-40^{\circ} \mathrm{C} \text { to } 60^{\circ} \mathrm{C} \\
\text { Measurement range: }-40{ }^{\circ} \mathrm{C} \text { to } 60{ }^{\circ} \mathrm{C} / 10 \% \mathrm{RH} \text { to } 95 \% \mathrm{RH} \\
\text { Accuracy at } 20^{\circ} \mathrm{C}: \pm 0.3^{\circ} \mathrm{C} / \pm 2.5 \% \mathrm{RH}\end{array}$ \\
\hline $\begin{array}{l}\text { Outdoor temperature and relative humidity } \\
\text { transmitter (HygroFlex HF535) }\end{array}$ & $\begin{array}{l}\text { Operating temperature: }-40^{\circ} \mathrm{C} \text { to } 60{ }^{\circ} \mathrm{C} \\
\text { Measurement range: }-40{ }^{\circ} \mathrm{C} \text { to } 60{ }^{\circ} \mathrm{C} / 0 \% \mathrm{RH} \text { to } 100 \% \mathrm{RH} \\
\text { Accuracy at } 23^{\circ} \mathrm{C}: \pm 0.1^{\circ} \mathrm{C} / \pm 0.8 \% \mathrm{RH}\end{array}$ \\
\hline Data logger for monitoring (Yokogawa WE7241) & $\begin{array}{c}\text { Measurement accuracy: } \pm\left(0.1 \% \text { of reading }+1{ }^{\circ} \mathrm{C}\right) \text {, except }-200{ }^{\circ} \mathrm{C} \text { to } 0{ }^{\circ} \mathrm{C} \text {, } \\
\pm\left(0.6 \% \text { of reading }+1{ }^{\circ} \mathrm{C}\right) \text { for thermocouple; } \pm(0.07 \% \text { of reading }+40 \mathrm{mV}) \\
\text { for pyranometer; } \pm(0.2 \% \text { of reading }+3 \mathrm{mV}) \text { for air temperature } / \text { relative } \\
\text { humidity transmitter }\end{array}$ \\
\hline Infrared thermal camera (Fluke Ti32) & $\begin{array}{l}\text { Operating temperature: }-10{ }^{\circ} \mathrm{C} \text { to } 50{ }^{\circ} \mathrm{C} \\
\text { Infrared spectral band: } 7.5 \mu \mathrm{m} \text { to } 14 \mu \mathrm{m} \\
\text { Measurement range: }-20{ }^{\circ} \mathrm{C} \text { to } 600{ }^{\circ} \mathrm{C} \\
\text { Thermal sensitivity: } \leq 0.05^{\circ} \mathrm{C} \\
\text { Accuracy: } \pm 2{ }^{\circ} \mathrm{C} \text { or } \pm 2 \%\end{array}$ \\
\hline
\end{tabular}




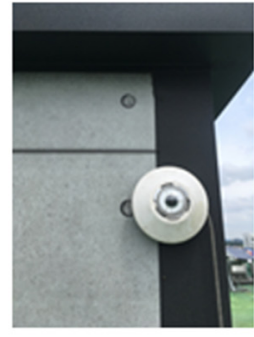

(a) Pyranometer mounted on vertical surface

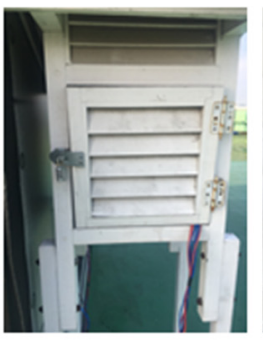

(b) Outdoor temperature and relative humidity transmitter in shielded cage

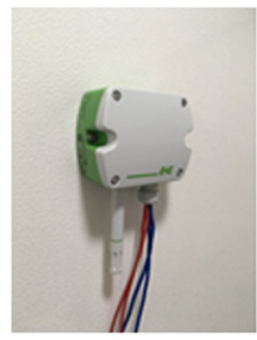

(c) Wall-mounted indoor temperature and relative humidity transmitter

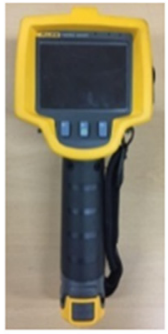

(d) IR camera

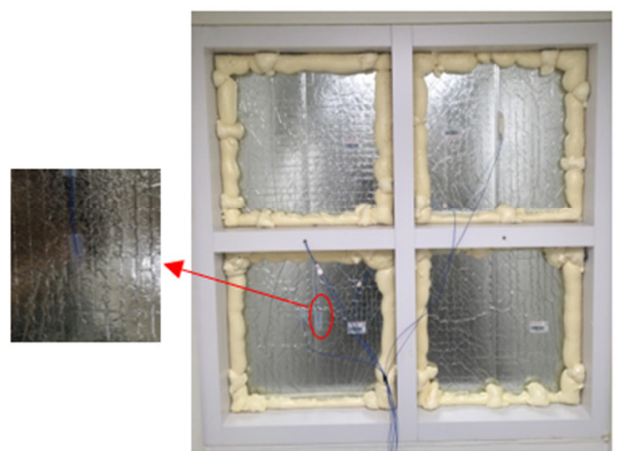

(e) Thermocouples installed on interio spandrel surface, and on VIP surface inside the spandrel cavity

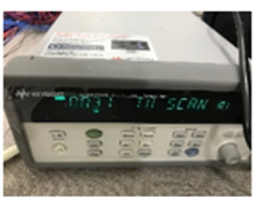

(f) Data logger for monitoring

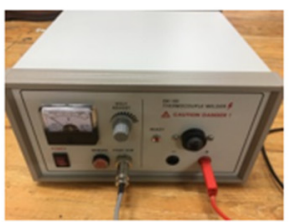

(g) Thermocouple welder

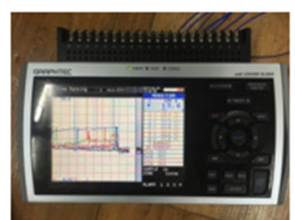

(h) Data logger for thermocouple calibration

Figure 8. Mockup measurement apparatus.
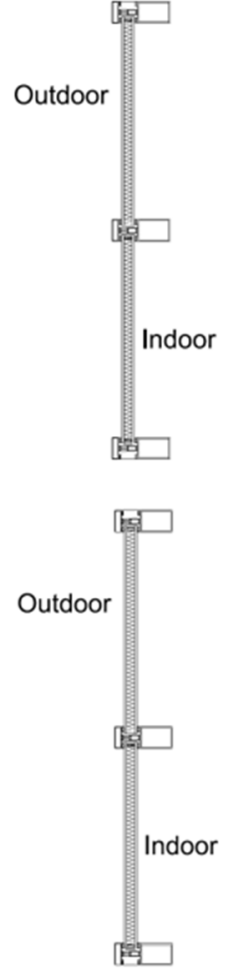

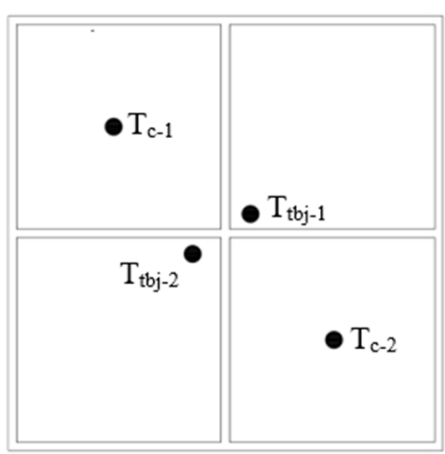

(a)

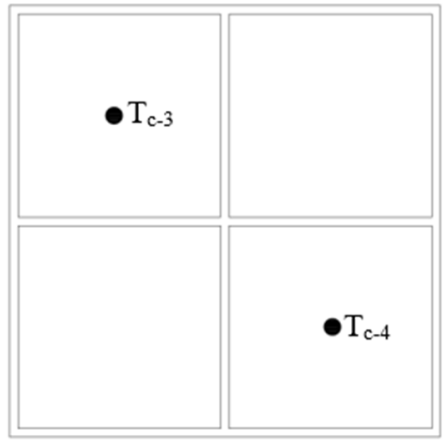

(b)

Figure 9. Schematic of thermocouple positions for: (a) interior and (b) exterior surfaces of spandrels. 
Table 6. Summary of number of thermocouples.

\begin{tabular}{cccc}
\hline Sensor Locations & Case 1 & Case 2 & Case 3 \\
\hline Interior surface (indoor) & 4 & 4 & 4 \\
Exterior surface (outdoor) & 2 & 2 & 2 \\
Surface of VIP (inside spandrel cavity) & 2 & 2 & 4 \\
\hline
\end{tabular}

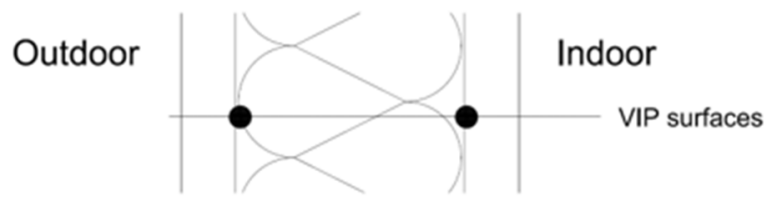

(a) Case 1

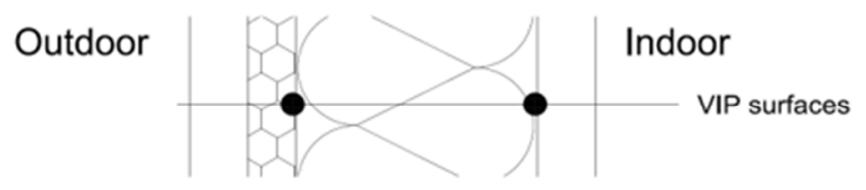

(b) Case 2

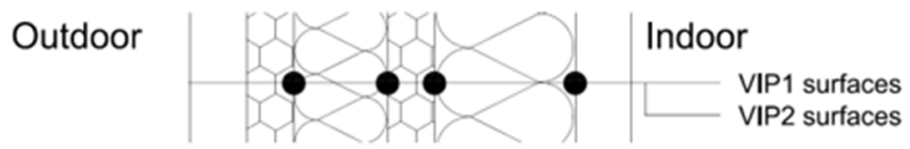

(c) Case 3

Figure 10. Thermocouple positions at VIP surfaces inside the spandrel cavity.

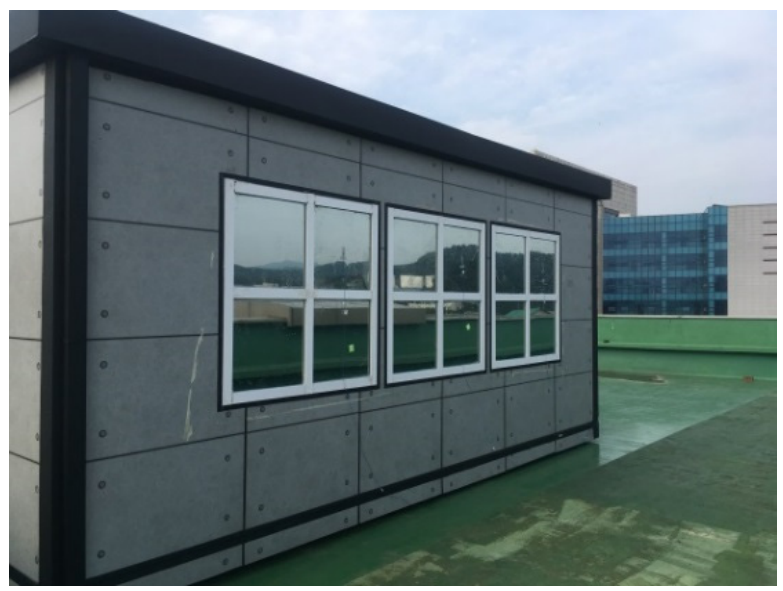

Figure 11. Mockup test facility with installed VIP spandrels.

\section{Results and Discussion}

In this section, the key results obtained from in lab assessments, numerical evaluations, and outdoor monitoring investigations are reported chronologically. Detailed discussions are also presented. Final reflections, limitations and challenges of the study are clearly stated as well to clearly define the repeatability, scope, and possibilities for further study.

\subsection{Thermal Characteristics of VIPS}

VIP samples were kept at room conditions for 60 days to observe and discard faulty panels emanating from manufacturing defects. At the end of the 60 days, all VIPs showed no anomalies or vacuum loss and were in good physical condition. Thereafter, the experimental evaluations commenced. In all, 22 VIPs were tested and used in this study. Table 7 
summarizes the dimensions, center-of-panel thermal conductivity, and inner pressure of the VIPs. Figure 12 shows a graphical analysis for a VIP (sample No. 1), used to determine internal pressure for the panel.

Table 7. Summary of VIP properties.

\begin{tabular}{|c|c|c|c|}
\hline Sample No. & Dimension, $\mathrm{mm} \times \mathbf{m m} \times \mathbf{m m}$ & $\begin{array}{l}\text { Center-of-Panel Thermal Conductivity } \\
\left(\lambda_{\text {cop }}\right), \mathrm{W} / \mathrm{mK}\end{array}$ & Inner Pressure $(p)$, mbar \\
\hline 1 & $600 \times 600 \times 25$ & 0.00430 & 4.0 \\
\hline 2 & $600 \times 600 \times 25$ & 0.00428 & 4.0 \\
\hline 3 & $600 \times 600 \times 25$ & 0.00379 & 4.5 \\
\hline 4 & $600 \times 600 \times 25$ & 0.00392 & 4.0 \\
\hline 5 & $600 \times 600 \times 25$ & 0.00395 & 5.5 \\
\hline 6 & $600 \times 600 \times 25$ & 0.00382 & 5.0 \\
\hline 7 & $600 \times 600 \times 25$ & 0.00382 & 4.0 \\
\hline 8 & $600 \times 600 \times 25$ & 0.00386 & 4.0 \\
\hline 9 & $600 \times 600 \times 25$ & 0.00456 & 4.0 \\
\hline 10 & $600 \times 600 \times 25$ & 0.00438 & 4.0 \\
\hline 11 & $600 \times 600 \times 15$ & 0.00397 & 5.0 \\
\hline 12 & $600 \times 600 \times 15$ & 0.00396 & 5.5 \\
\hline 13 & $600 \times 600 \times 15$ & 0.00396 & 5.5 \\
\hline 14 & $600 \times 600 \times 15$ & 0.00400 & 5.0 \\
\hline 15 & $600 \times 600 \times 15$ & 0.00402 & 6.0 \\
\hline 16 & $600 \times 600 \times 15$ & 0.00405 & 5.0 \\
\hline 17 & $600 \times 600 \times 10$ & 0.00420 & 5.5 \\
\hline 18 & $600 \times 600 \times 10$ & 0.00412 & 4.5 \\
\hline 19 & $600 \times 600 \times 10$ & 0.00426 & 6.0 \\
\hline 20 & $600 \times 600 \times 10$ & 0.00424 & 7.0 \\
\hline 21 & $600 \times 600 \times 10$ & 0.00426 & 6.0 \\
\hline 22 & $600 \times 600 \times 10$ & 0.00437 & 6.5 \\
\hline
\end{tabular}

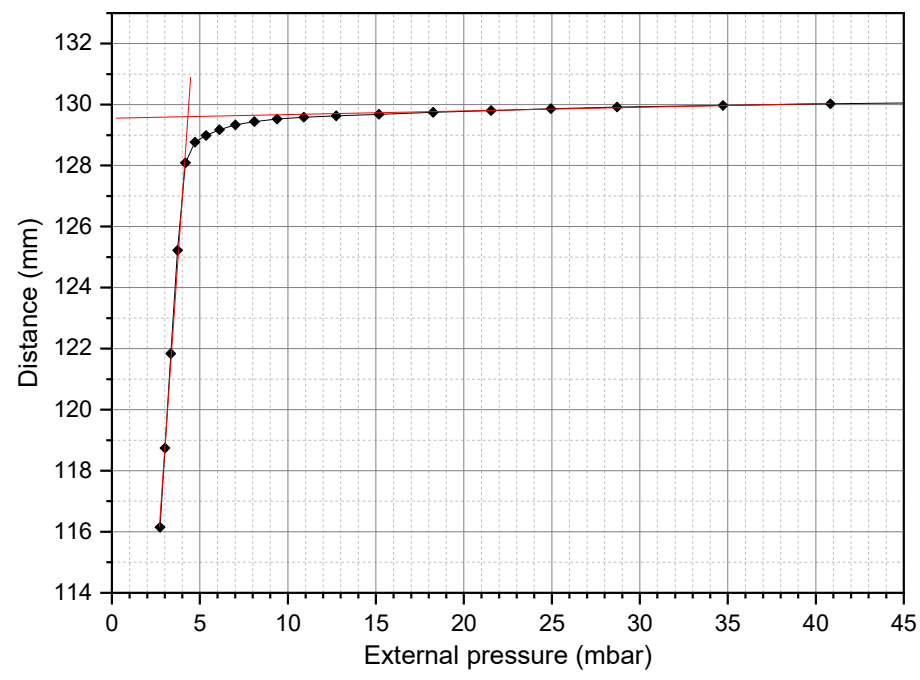

Figure 12. Determination of inner pressure for VIP (sample No. 1).

All other VIP samples showed similar graphical trends. The pressure in the vacuum chamber of the test apparatus equaled atmospheric pressure at the beginning of the inner pressure measurement. As pressure reduced inside the vacuum chamber (due to the working action of vacuum pumps), the pressure inside the vacuum chamber dropped continuously until a point where the envelope of the VIP lifted from the core momentarily. This was the critical pressure where the two extrapolated curves met. This critical point gave an indication of the inner pressure of each VIP. On the one hand, the mean center-of-panel thermal conductivity and mean inner pressure for VIPs with dimensions 
$600 \mathrm{~mm} \times 600 \mathrm{~mm} \times 25 \mathrm{~mm}, 600 \mathrm{~mm} \times 600 \mathrm{~mm} \times 15 \mathrm{~mm}$, and $600 \mathrm{~mm} \times 600 \mathrm{~mm} \times 10 \mathrm{~mm}$ was about $0.0041 \mathrm{~W} / \mathrm{mK}, 0.0040 \mathrm{~W} / \mathrm{mK}$, and $0.0042 \mathrm{~W} / \mathrm{mK}$, respectively. On the other hand, the mean inner pressure for VIPs with dimensions $600 \mathrm{~mm} \times 600 \mathrm{~mm} \times 25 \mathrm{~mm}$, $600 \mathrm{~mm} \times 600 \mathrm{~mm} \times 15 \mathrm{~mm}$, and $600 \mathrm{~mm} \times 600 \mathrm{~mm} \times 10 \mathrm{~mm}$ was estimated to be 4.3 mbar, 5.3 mbar, and 5.9 mbar, correspondingly. The linear thermal bridge (Figure 13) at one edge of the panel was estimated to be $0.008 \mathrm{~W} / \mathrm{mK}$ for the $25 \mathrm{~mm} \mathrm{VIP}, 0.011 \mathrm{~W} / \mathrm{mK}$ for the $15 \mathrm{~mm} \mathrm{VIP}$, and $0.013 \mathrm{~W} / \mathrm{mK}$ for the $10 \mathrm{~mm}$ VIP.

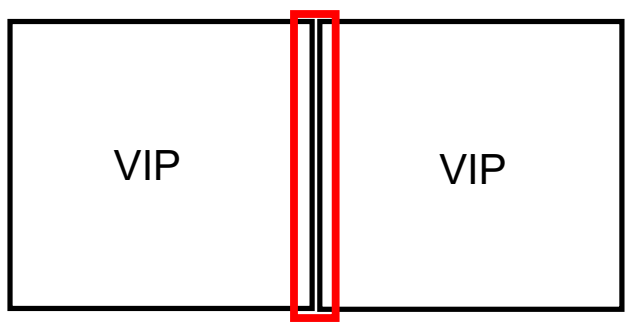

Figure 13. Schematic showing thermal bridge (marked in red) between VIPs.

The edge effect $\left(\Delta_{e d g e}\right)$ and effective thermal conductivity $\left(\lambda_{e f f}\right)$ were computed based on Equations (1) and (2):

$$
\begin{gathered}
\Delta_{\text {edge }}=\psi(d) \times d \times p / A \\
\lambda_{\text {eff }}=\lambda_{\text {cop }}+\Delta_{\text {edge }}
\end{gathered}
$$

where $\psi(d)$ is linear thermal transmittance at the edge of the panel $(\mathrm{W} / \mathrm{mK})$ and $d, p$, and $A$ are the thickness $(\mathrm{m})$, perimeter $(\mathrm{m})$, and area $\left(\mathrm{m}^{2}\right)$ of the panel, respectively. Thermal characterization results for VIPs are summarized in Table 8.

Table 8. Summary of VIP thermal conductivity characterization.

\begin{tabular}{cccc}
\hline Description & $\mathbf{2 5} \mathbf{~ m m ~ V I P ~}$ & $\mathbf{1 5} \mathbf{~ m m ~ V I P ~}$ & $\mathbf{1 0 ~} \mathbf{~ m m ~ V I P}$ \\
\hline $\begin{array}{c}\text { Mean center-of-panel thermal } \\
\text { conductivity, W/mK }\end{array}$ & 0.0041 & 0.0040 & 0.0042 \\
$\begin{array}{c}\text { Linear thermal transmittance, W/mK } \\
\begin{array}{c}\text { Effective thermal conductivity } \\
\text { (including thermal bridge), } \mathrm{W} / \mathrm{mK}\end{array}\end{array}$ & 0.008 & 0.011 & 0.013 \\
\hline
\end{tabular}

\subsection{Numerical Evaluations of Insulation Performance for VIP Spandrels}

Table 9 summarizes the simulation results at steady state conditions. Figure 14 represents thermal gradients for the overall system and sectional details for the VIP spandrels.

Table 9. Thermal performance of various curtain wall spandrel configurations.

\begin{tabular}{cccc}
\hline Description & Case 1 & Case 2 & Case 3 \\
\hline $\begin{array}{c}\text { Linear thermal transmittance, } \psi \\
(\mathrm{W} / \mathrm{mK})\end{array}$ & 0.23 & 0.22 & 0.19 \\
$\begin{array}{c}\text { 1-D thermal transmittance, } U_{1-D} \\
\left(\mathrm{~W} / \mathrm{m}^{2} \mathrm{~K}\right)\end{array}$ & 0.21 & 0.20 & 0.18 \\
$\begin{array}{c}\text { Effective thermal transmittance, } U_{\text {eff }} \\
\left(\mathrm{W} / \mathrm{m}^{2} \mathrm{~K}\right)\end{array}$ & 0.87 & 0.85 & 0.84 \\
$\begin{array}{c}13.8^{\circ} \mathrm{C} \\
\text { Lowest indoor surface temperature } \\
\text { Lowest temperature factor }\end{array}$ & 0.57 & $14.3^{\circ} \mathrm{C}$ & $14.3^{\circ} \mathrm{C}$ \\
\hline
\end{tabular}



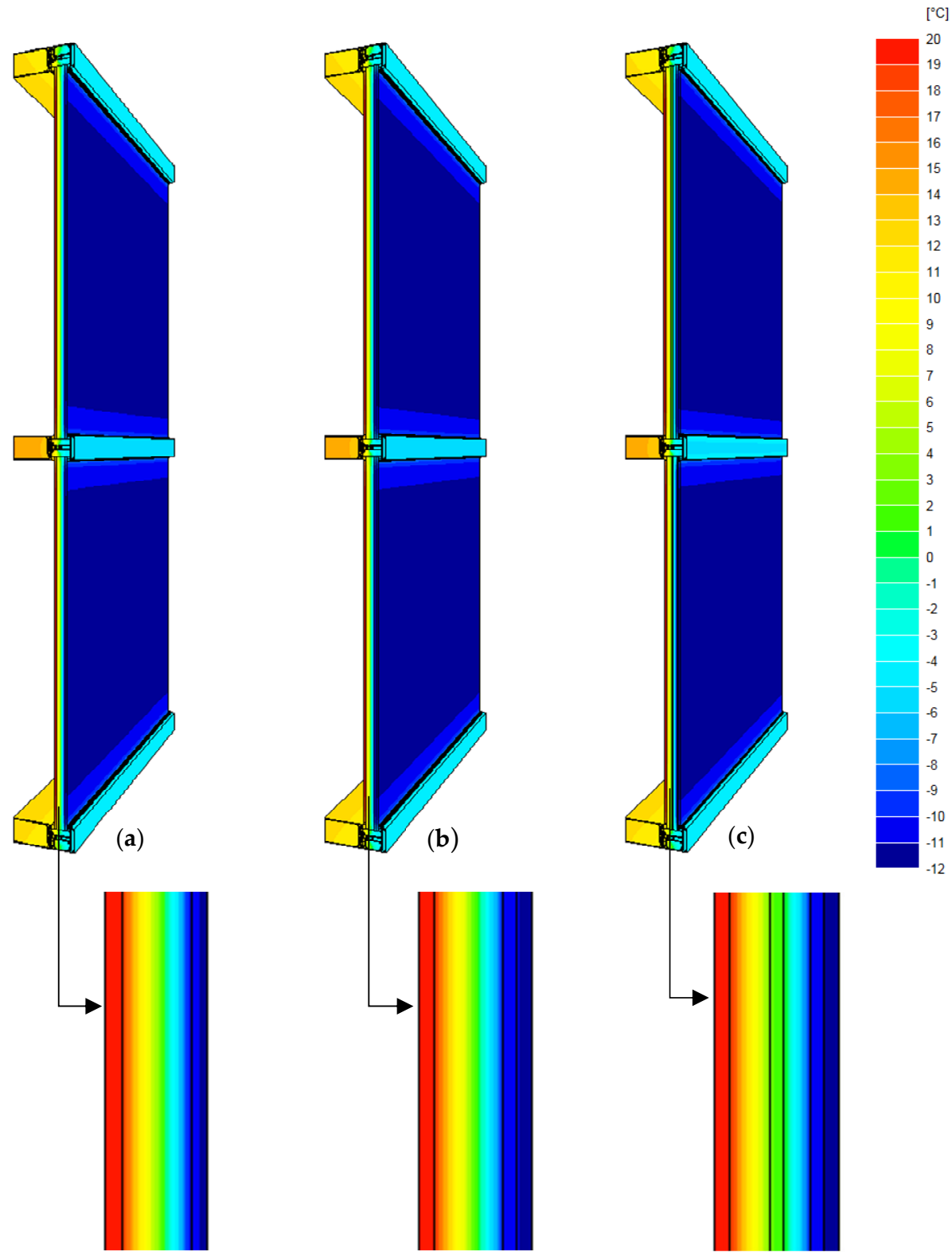

Figure 14. Temperature distributions of overall system and across VIP spandrel sections: (a) Case 1, (b) Case 2, and (c) Case 3.

As expected, the one-dimensional thermal transmittance $\left(U_{1-D}\right)$ of VIP spandrel elements was lowest for Case 3 because of the additional layers of XPS. Nonetheless, the linear thermal transmittance $(\psi)$ of the cases can be ranked in the order: Case $3>$ Case $2>$ Case 1 . This is rightly attributed to the configuration of the sandwich VIP spandrel components. The effective thermal transmittance $\left(U_{e f f}\right)$, which factors thermal contributions of the framing component, followed a similar trend. It is worth noting that the center-of-spandrel $U_{1-D}$ for VIP spandrels is more than four times lower than the reported $U_{1-D}$ for the spandrel with $100 \mathrm{~mm}$ thick mineral wool insulation [20]. For all the spandrel cases, the lowest indoor surface temperature was found around the junctions of the spandrel element and framing component. The lowest indoor surface temperatures can be ranked as: Case 3 $\left(14.3^{\circ} \mathrm{C}\right)=$ Case $2\left(14.3^{\circ} \mathrm{C}\right)>$ Case $1\left(13.8^{\circ} \mathrm{C}\right)$. This is mainly due to the thermal insulation effect of the extra XPS layers for Case 2 and Case 3. Consequently, the lowest temperature factor $\left(T_{f}\right)$ for the cases can be ranked in the order: Case $3(0.67)>$ Case $2(0.66)>$ Case $1(0.57) . T_{f}$ is a dimensionless quantity that expresses the difference between internal surface temperature and external temperature divided by the difference between internal 
temperature and external temperature [70]. Practically, it can be used to assess the risk of surface condensation at the internal surface. The higher the $T_{f}$ coefficient, the lesser the risk of surface condensation. Some countries have set limits for $T_{f}$, for instance, in France ( $T_{f}>0.52$ at reference conditions of $T_{\text {out }}=0{ }^{\circ} \mathrm{C}, \mathrm{RH}=80 \%$, and $T_{\text {in }}=18{ }^{\circ} \mathrm{C}$ ), Germany ( $T_{f}$ of 0.87 ), and Estonia ( $T_{f}$ of 0.55 ) [71], and in the UK and Netherlands a $T_{f}$ of 0.50 is reported [60]. Thus, some researchers deduced that the definitive $T_{f}$ value is not solely based on indoor moisture access, building purpose, and ventilation status but also on the prevailing local climate [34]. For Case 1, Case 2, and Case 3, the $T_{f}$ values were all greater than 0.57 , with the highest being 0.67 for Case 3 . Therefore, surface condensation risk is not expected to occur. Concerning temperature distributions across VIP spandrels (Figure 14 bottom), the temperatures at the exterior and interior VIP surfaces were about $-10.9^{\circ} \mathrm{C}$ and $19.2^{\circ} \mathrm{C}$ for Case 1, respectively. Similarly for Case 2, the exterior and interior VIP surface temperatures were around $-9.8^{\circ} \mathrm{C}$ and $19.3^{\circ} \mathrm{C}$, respectively. For Case 3 , the temperature at the exterior surface of the outer lying $10 \mathrm{~mm}$ VIP was $-9.9^{\circ} \mathrm{C}$, while that for the interior surface was $1.4^{\circ} \mathrm{C}$. For the inner lying $15 \mathrm{~mm} \mathrm{VIP}$, the temperatures at its exterior and interior surfaces were $2.5^{\circ} \mathrm{C}$ and $19.3^{\circ} \mathrm{C}$, respectively. Based on boundary conditions and design factors used, the numerical results clearly show the thermal effects of the distinctive VIP spandrel configurations.

\subsection{Thermal Performance of In Situ VIP Spandrels}

The in situ VIP spandrel system's performance in a real-scale building has been monitored for over 1.5 years, and monitoring is still ongoing. Thus, for the sake of clarity, data for selected days will be presented in this manuscript. The results presented in this section are for representative cold winter days (4-6 February 2020).

\subsubsection{Thermal Bridge Evaluation}

Temperatures at the internal surface areas where the VIP spandrel intersected the Al frame (referred to as the VIP spandrel-Al frame thermal bridge junction, $\mathrm{T}_{\mathrm{tbj}}$ ) were measured and are summarized in Table 10.

Table 10. Summary of interior surface temperatures at the VIP spandrel-Al frame thermal bridge junction.

\begin{tabular}{|c|c|c|c|c|c|c|}
\hline \multirow{2}{*}{\multicolumn{2}{|c|}{ Description }} & \multirow{2}{*}{$\begin{array}{l}\text { Outdoor Air } \\
\text { Temperature } \\
\left({ }^{\circ} \mathrm{C}\right)\end{array}$} & \multirow{2}{*}{$\begin{array}{c}\text { Solar } \\
\text { Radiation } \\
\left(\mathrm{W} / \mathrm{m}^{2}\right)\end{array}$} & \multicolumn{3}{|c|}{$\begin{array}{l}\text { VIP Spandrel-Al Frame Thermal Bridge Junction Interior } \\
\text { Surface Temperature }\left({ }^{\circ} \mathrm{C}\right)\end{array}$} \\
\hline & & & & Case 1 & Case 2 & Case 3 \\
\hline \multirow[t]{4}{*}{ Day } & Max & -2.5 & 911.55 & 11.2 & 9.6 & 9.2 \\
\hline & Min & -8.8 & 1.43 & 1.7 & 2.6 & 3.2 \\
\hline & Avg & -4.4 & 581.48 & 6.8 & 6.3 & 6.1 \\
\hline & SD & 1.92 & 285.25 & 3.71 & 2.79 & 2.32 \\
\hline \multirow[t]{4}{*}{ Night } & Max & -5.8 & & 7.5 & 7.2 & 7.5 \\
\hline & Min & -10.9 & & -0.5 & 0.2 & 0.8 \\
\hline & Avg & -8.2 & & 2.4 & 3.1 & 3.6 \\
\hline & SD & 1.55 & & 2.14 & 1.89 & 1.86 \\
\hline
\end{tabular}

Max = maximum, Min = minimum, and SD = standard deviation.

Generally, by comparing temperatures at the VIP spandrel-Al frame thermal bridge junction (Table 10) with temperatures measured at the center of the VIP spandrels (Table 11), it can be deduced that average temperatures at thermal bridge junctions were higher than at the center of the spandrel. For instance, during the day, the $\mathrm{T}_{\max }$ at the spandrel-frame thermal bridge junction was $2.3{ }^{\circ} \mathrm{C}, 1.2^{\circ} \mathrm{C}$, and $0.6{ }^{\circ} \mathrm{C}$ higher than the $\mathrm{T}_{\max }$ at the center of the spandrel for Case 1, Case 2, and Case 3, respectively. The Case 1 spandrel was the one most affected by the thermal bridge junctions, as proved by the highest temperature differences coupled with the biggest deviations. Higher thermal bridge temperatures for Case 1 compared to Case 2 and Case 3 could also imply a higher magnitude of associated 
heat fluxes due to the junction thermal bridges. On the contrary, the Case 3 spandrel had the lowest temperature deviations at the spandrel-frame thermal bridge junctions. The thermal bridge characteristics of the Case 2 spandrel were, on average, between Case 1 and Case 2. During the night, $\mathrm{T}_{\min }$ at the spandrel-frame thermal bridge junction was $2{ }^{\circ} \mathrm{C}$, $1.2{ }^{\circ} \mathrm{C}$, and $1^{\circ} \mathrm{C}$ lower than $\mathrm{T}_{\min }$ at the center of the spandrel for Case 1, Case 2, and Case 3 , respectively. Therefore, during daytime, maximum temperatures at the spandrel-frame thermal bridge junction areas were higher than at the center of the spandrels, while at night-time, minimum temperatures at the spandrel-frame thermal bridge junction areas were lower than at the center of the spandrels. This indicates that the existence of thermal bridges, particularly caused by the framing element, cannot be marginalized because the internal surface temperature profile could be influenced by outdoor conditions due to the existence of the spandrel-frame junction thermal bridges. Nonetheless, concerning resistance to spandrel-frame thermal bridges, the VIP spandrel cases can be ranked in the order: Case $3>$ Case $2>$ Case 1. The VIP spandrel configuration for Case 3, applying extra layers of XPS insulation, is the main contributing factor to its being the least affected by spandrel-frame thermal bridges.

Table 11. Summary of temperature at interior surfaces of the VIP and spandrel (measured at center position).

\begin{tabular}{|c|c|c|c|c|c|c|c|c|c|}
\hline \multirow{2}{*}{\multicolumn{2}{|c|}{ Description }} & \multirow{2}{*}{$\begin{array}{l}\text { Outdoor Air } \\
\text { Temperature } \\
\quad\left({ }^{\circ} \mathrm{C}\right)\end{array}$} & \multirow{2}{*}{$\begin{array}{c}\text { Solar } \\
\text { Radiation } \\
\left(\mathrm{W} / \mathrm{m}^{2}\right)\end{array}$} & \multicolumn{3}{|c|}{ VIP Interior Surface Temp. $\left({ }^{\circ} \mathrm{C}\right)$} & \multicolumn{3}{|c|}{$\begin{array}{c}\text { Spandrel Interior Surface Temp. } \\
\left({ }^{\circ} \mathrm{C}\right)\end{array}$} \\
\hline & & & & Case 1 & Case 2 & Case 3 & Case 1 & Case 2 & Case 3 \\
\hline \multirow[t]{4}{*}{ Day } & Max & -2.5 & 911.55 & 8.7 & 8.5 & 8.5 & 8.9 & 8.4 & 8.6 \\
\hline & Min & -8.8 & 1.43 & 3.7 & 3.7. & 4 & 3.9 & 3.9 & 4.2 \\
\hline & Avg & -4.4 & 581.48 & 6.2 & 5.89 & 6.09 & 6.3 & 5.9 & 6.1 \\
\hline & $\mathrm{SD}$ & 1.92 & 285.25 & 1.90 & 1.75 & 1.68 & 1.82 & 1.64 & 1.58 \\
\hline \multirow[t]{4}{*}{ Night } & Max & -5.8 & & 7.4 & 7.2 & 7.6 & 7.5 & 7.3 & 7.7 \\
\hline & Min & -10.9 & & 1.4 & 1.3 & 1.6 & 1.5 & 1.4 & 1.8 \\
\hline & Avg & -8.2 & & 4.0 & 3.9 & 4.3 & 4.2 & 4.1 & 4.5 \\
\hline & $\mathrm{SD}$ & 1.55 & & 1.72 & 1.69 & 1.69 & 1.68 & 1.67 & 1.66 \\
\hline
\end{tabular}

Max = maximum, Min = minimum, and SD = standard deviation.

\subsubsection{Temperature Characteristics at Internal and External VIP/Spandrel Surfaces}

The temperature evolution at internal VIP surfaces (inside the spandrel cavity) are plotted in Figure 15, while a summary including spandrel surface temperatures is presented in Table 11. The VIP internal surface is the surface of the panel facing indoors. Similarly, spandrel internal surface is the surface of the spandrel facing indoors.

The thermal performance of the spandrel alternatives was reasonable, however, with subtle but clear differences. From Table 11, it can be seen that, during the day, the Case 1 spandrel had the maximum interior surface temperature, while showing higher fluctuations, resulting in the highest deviation. This is likely because of high heat fluxes for the Case 1 spandrel compared to the other spandrel cases. Consequently, among the spandrel cases, the Case 1 spandrel was the most susceptible to fluctuating outdoor weather conditions. Conversely, the Case 3 spandrel had the least standard deviation facilitated by the highest minimum surface temperature. This is attributed to the superior thermal resistance of the Case 3 spandrel aided by the incorporation of XPS insulation within the spandrel to primarily restrict thermal bridge effects, which also improved the spandrel's insulation performance. The thermal behavior of the Case 2 spandrel was roughly between the Case 1 and Case 3 spandrels. Moreover, these specific characteristics reflected the thermal performance of the spandrel cases at night-time. Referring to Table 11, during the night (with outdoor temperatures ranging from -5.8 to $-10.9{ }^{\circ} \mathrm{C}$ ), internal surface temperatures for the Case 3 spandrel recorded the highest (maximum, minimum, and average) surface temperatures, which corresponded to an average of about $0.3{ }^{\circ} \mathrm{C}$ higher than those recorded for the Case 1 and Case 2 spandrels. The results are in agreement with 
previous findings in the literature, allowing the conclusion that the double-layer VIP design had better insulation performance compared to the single-layer VIP design [72].

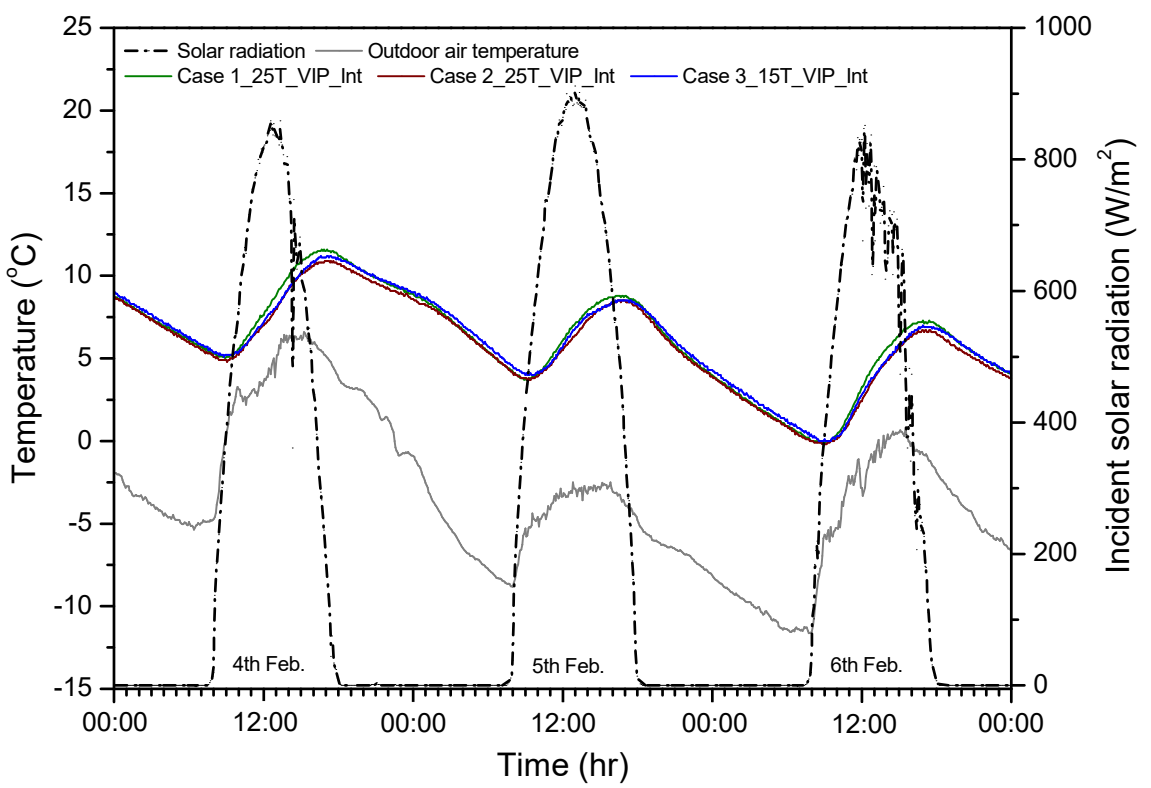

Figure 15. Temperature fluctuations at interior VIP surfaces inside the spandrel cavity.

Similarly, temperature fluctuations at external VIP surfaces (inside the spandrel cavity) are plotted in Figure 16, while a summary including spandrel surface temperatures is reported in Table 12.

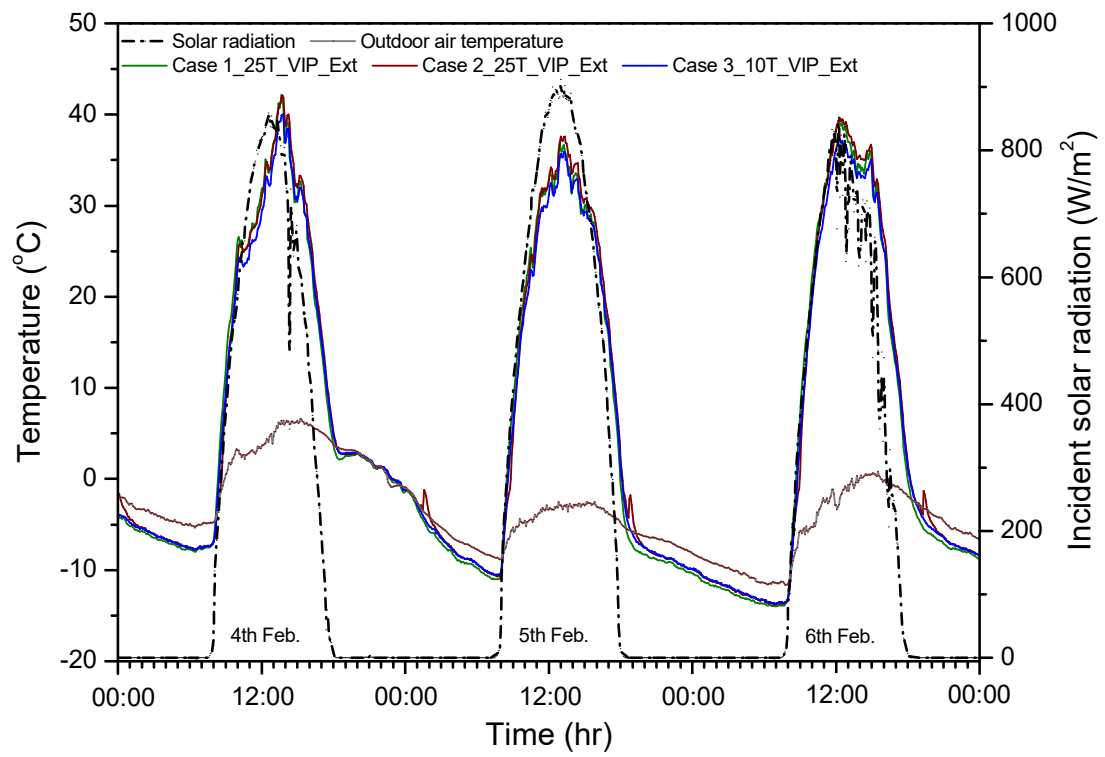

Figure 16. Temperature characteristics at exterior VIP surfaces inside the spandrel cavity. 
Table 12. Summary of temperature at the exterior surfaces of the VIP and spandrel (measured at center position).

\begin{tabular}{|c|c|c|c|c|c|c|c|c|c|}
\hline \multirow{2}{*}{\multicolumn{2}{|c|}{ Description }} & \multirow{2}{*}{$\begin{array}{l}\text { Outdoor Air } \\
\text { Temperature } \\
\quad\left({ }^{\circ} \mathrm{C}\right)\end{array}$} & \multirow{2}{*}{$\begin{array}{c}\text { Solar } \\
\text { Radiation } \\
\left(\mathrm{W} / \mathrm{m}^{2}\right)\end{array}$} & \multicolumn{3}{|c|}{ VIP Exterior Surface Temp. $\left({ }^{\circ} \mathrm{C}\right)$} & \multicolumn{3}{|c|}{$\begin{array}{l}\text { Spandrel Exterior Surface Temp. } \\
\left({ }^{\circ} \mathrm{C}\right)\end{array}$} \\
\hline & & & & Case 1 & Case 2 & Case 3 & Case 1 & Case 2 & Case 3 \\
\hline \multirow[t]{4}{*}{ Day } & Max & -2.5 & 911.55 & 37 & 37.6 & 35.9 & 31.3 & 32.7 & 31.8 \\
\hline & Min & -8.8 & 1.43 & -11 & -10.7 & -10.5 & -11.3 & -11.2 & -11.2 \\
\hline & Avg & -4.4 & 581.48 & 20.8 & 20.9 & 19.9 & 16.8 & 17.5 & 17 \\
\hline & $\mathrm{SD}$ & 1.92 & 285.25 & 14.75 & 15.54 & 14.61 & 12.83 & 13.22 & 12.85 \\
\hline \multirow[t]{4}{*}{ Night } & Max & -5.8 & & -7.5 & -4.8 & -6.3 & -8 & -8 & -7.9 \\
\hline & Min & -10.9 & & -13.4 & -13 & -12.9 & -13.8 & -13.8 & -13.6 \\
\hline & Avg & -8.2 & & -10.6 & -10 & -10 & -10.9 & -10.9 & -10.7 \\
\hline & SD & 1.55 & & 1.73 & 1.95 & 1.81 & 1.72 & 1.72 & 1.74 \\
\hline
\end{tabular}

Max = maximum, Min = minimum, and SD = standard deviation.

The VIP external surface is the surface of the panel facing outdoors. Likewise, the spandrel external surface is the surface of the spandrel facing outdoors. Generally, the temperature profiles at the external surfaces of the VIPs and spandrels fluctuated with outdoor conditions. Nonetheless, during the day, external surface temperatures (measured at the center of panel and spandrel surfaces) were higher than outdoor air temperatures due to solar radiation incident on a highly insulated surface. However, at night, external temperatures for VIP and spandrel surfaces were dictated by outdoor temperature conditions due to night sky radiation effects. The spandrels showed similar exterior surface temperature profiles.

\subsubsection{Heat Losses/Gains}

Table 13 reports and compares results for heat losses/gains for both experimental and numerical procedures. Both experimental and numerical computations showed a similar trend with a mean agreement margin of about $10 \%$. One plausible reason for this difference is that, as a limitation, the simulation tool used could not factor the effect of the UV protective control film. Reasonably, the numerically computed heat losses were slightly higher. Nonetheless, the overall heat loss/gain of the cases can be ranked in the order: Case $3<$ Case $2<$ Case 1 .

Table 13. Comparison of experimental and numerical results for heat loss/gain.

\begin{tabular}{cccc}
\hline Description & Case 1 & Case 2 & Case 3 \\
\hline Experimental (calculated average), W & 3.51 & 3.42 & 3.23 \\
Numerical (steady state simulation), W & 3.90 & 3.74 & 3.60 \\
\hline
\end{tabular}

\subsection{Durability of VIPs in Spandrel Cavities}

Thermocouples were installed on the external and internal surfaces of the VIPs (inside the spandrel cavity) and on the spandrel surface to measure temperature variations. Throughout the months of monitoring, temperature measurements have been within the same range of values, indicating the integrity of the panels and proving that the performance of the VIPs is stable to date. In addition, the VIP integrated spandrels were configurated in such a manner that the internal facing VIP surfaces can be visually seen through transparent glazing. It is well known that VIP failure is accompanied by bulges of the envelope material (caused by moisture uptake), which is quite visible even in an opaque building façade. To date, no such phenomenon has been observed. Finally, IR thermographic investigations were conducted from time to time. Figure 17 displays IR thermal images taken from the interior on 28th June 2019 at mean indoor relative humidity and temperature conditions of about $55 \%( \pm 5)$ and $24^{\circ} \mathrm{C}( \pm 1)$ respectively. The emissivity for the measurements was 0.92 . Generally, the mean spandrel surface temperature was 
lower than for the frame temperature. Noticeable areas of heat loss or gain were observed along the edges of the aluminum frames, which agrees well with the results presented in Section 3.3. The IR images also show that the VIPs performed satisfactorily with no failure.

\subsection{Further Reflections}

Regarding the discussed results for any performance index, Case 2 often showed average characteristics, with Case 1 and Case 3 presenting extremes. Case 1 was particularly easy to fabricate due to its relatively simple design. Mainly due to its single-layer VIP configuration, Case 1 had the highest linear thermal transmittance and consequently the highest effective $U$-value, accompanied by a higher thermal bridge at the spandrel-Al frame junctions. In addition, its tolerance for surface condensation was not comparable to Case 2 and Case 3, as evidenced by the lowest indoor surface temperature and temperature factor. Although satisfactory, under steady state conditions and very high relative humidity conditions, surface condensation could occur, theoretically. Conversely, Case 3 showed the strongest case for resistance against surface condensation. It is worth noting that the thermal performance of Case 2 and Case 3 VIP spandrels was almost comparable. However, boosted by a double-layer VIP configuration, together with face-covering XPS layers, Case 3 had the lowest one-dimensional $U$-value. Both experimental assessments and numerical computations proved that the outer lying VIP protected the inner lying VIP from fluctuating and direct outdoor conditions, particularly soaring temperatures due to solar radiation. This resulted in an average temperature difference of about $15^{\circ} \mathrm{C}$ according to experimental results and $12{ }^{\circ} \mathrm{C}$ according to numerical computations. The double-layer design coupled with the XPS face coverings raised the temperature of the VIP surface, which is a phenomenon that restricts moisture transport. This observation was unique to Case 3. In addition, the Case 3 spandrel showed the best resistance against spandrel-Al frame junction thermal bridges and related heat losses or gains. Based on the study conditions and results, it can be deduced that Case 3 is the most improved configuration for the integration of VIPs in curtain walls as spandrel insulation. The only downside of Case 3 is that, due to its multilayered design, it is not the easiest configuration to fabricate.

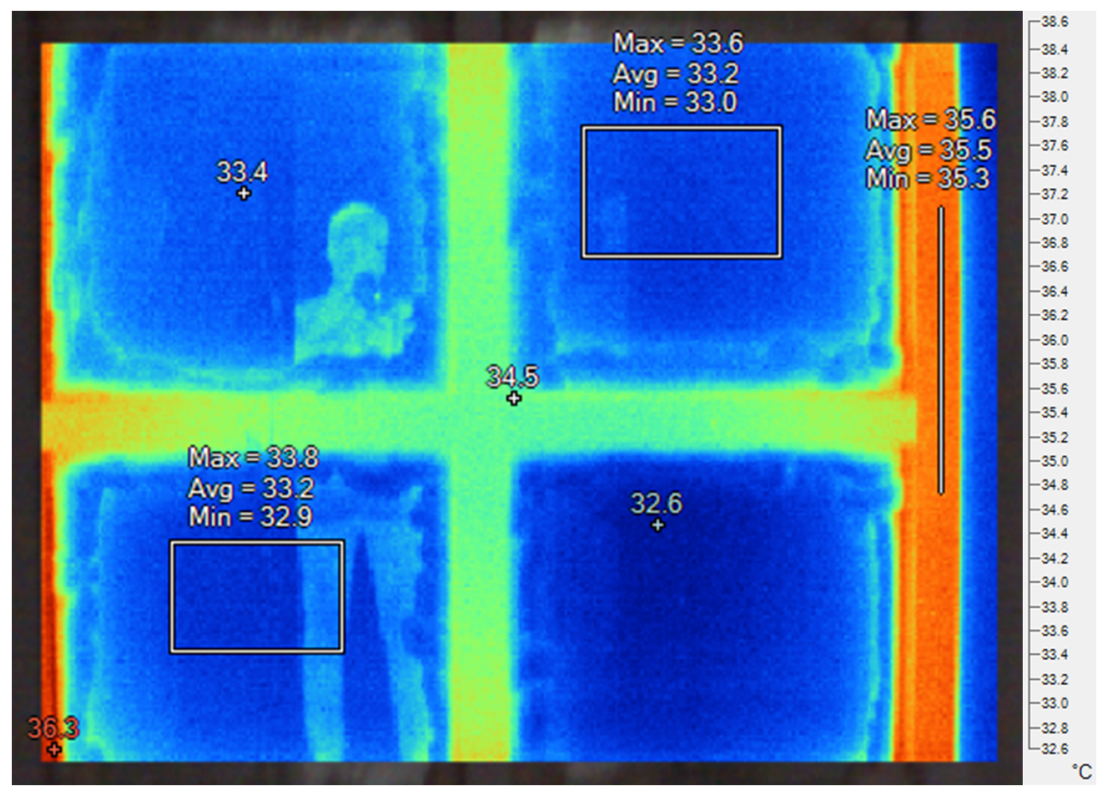

(a)

Figure 17. Cont. 


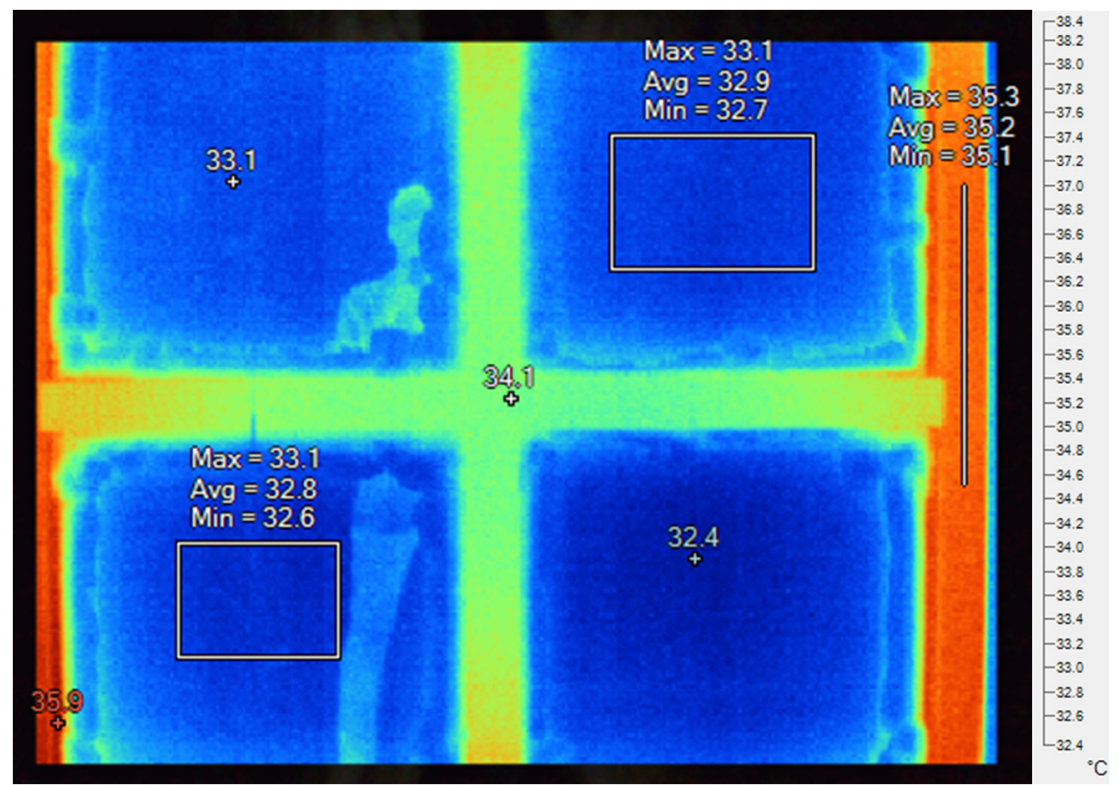

(b)

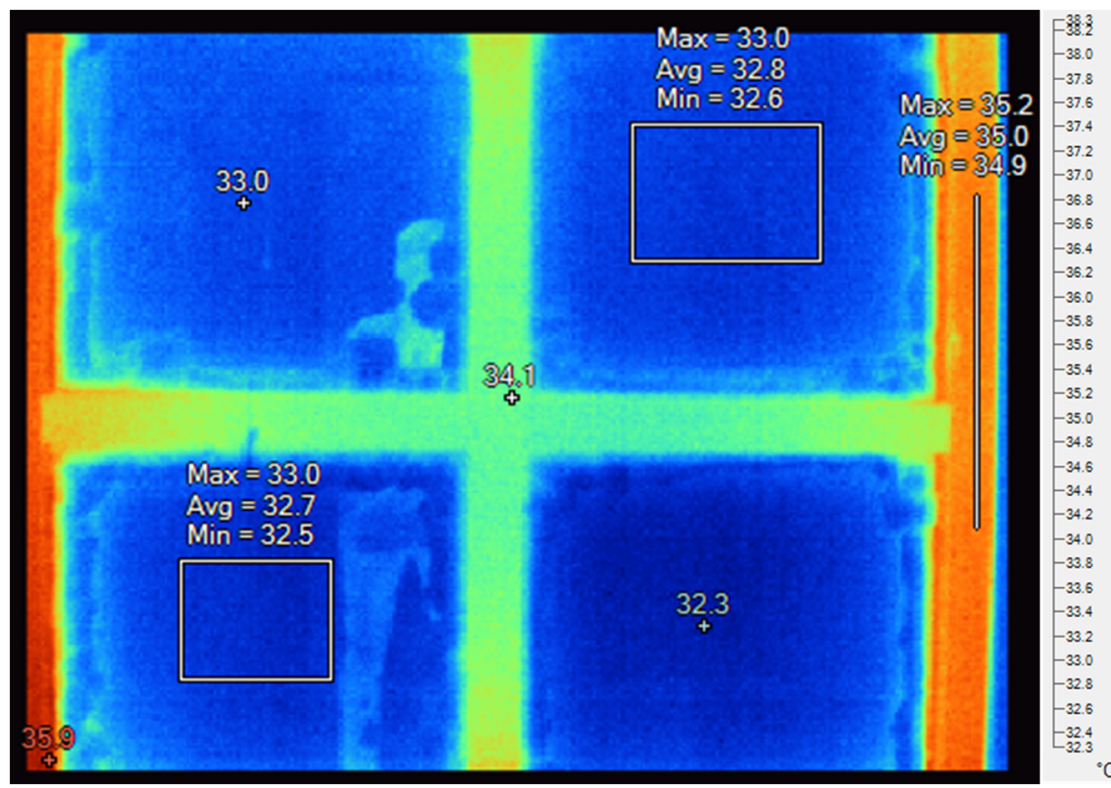

(c)

Figure 17. IR thermal images. (a) Case 1; (b) Case 2; (c) Case 3.

\subsection{Limitations and Challenges}

For VIP enclosures, it is important to know the conditions that the panels can be subjected to in real applications. Temperature and moisture transport have been identified in the literature as some of the key mechanisms driving the aging of VIP. So, an idea of the prevailing hygrothermal conditions, especially inside the spandrel cavity, are also necessary to design a suitable scheme for VIP integration into curtain wall spandrels. However, most humidity measuring apparatuses are bulky and cannot easily fit on the surface of the VIP within the slim space of the spandrel cavity. So, for this study, hygrothermal conditions outside the VIP spandrel were easily measured, but only the temperature inside the VIP spandrel was assessed. This challenge calls for more robust VIP spandrel designs that can accommodate the size of humidity measuring tools without compromising the durability of the VIP or the overall system. Alternatively, small sized humidity testers could also be suitable solutions. Secondly, various approaches can be used to evaluate the durability of 
VIPs inside a spandrel cavity. The quickest method involved using an IR camera which instantaneously produced thermal imaging for analysis. Nonetheless, the surfaces of the VIP spandrel, especially the exterior surface, was reflective because of solar radiation incident on the outer glass material. So, techniques were needed to overcome this challenge. The approach used in this study was to carry out the IR camera investigations after midday, when the sun azimuth was not highest. This approach was examined using a conventional brick façade and the results were found to be accurately repeatable. Finally, this study contributes substantially to VIP applications, particularly in curtain wall constructions. Nonetheless, due to convenience and cost factors, VIP spandrels were tested using standard window frames. Since this study concerned the thermal characterization of VIP spandrels and not their structural properties, this approach was conveniently adequate. Additionally, because of size limitations of the mockup test building facility, large size VIP spandrels could not be tested. Going forward, opportunities to evaluate the thermal and insulation performance of bigger sized VIP spandrels in large-scale curtain walls is needed.

\section{Conclusions and Outlook}

In this study, the thermal performance of curtain wall spandrels integrated with vacuum insulation panels (VIPs) as spandrel insulation has been investigated. To this purpose, three VIP spandrel alternatives were fabricated and tested in a mockup test building. Case 1 and Case 2 both utilized single-layer $25 \mathrm{~mm}$ VIP, whereas Case 3 used double-layered VIP of thicknesses $10 \mathrm{~mm}$ (towards outdoors) and $15 \mathrm{~mm}$ (towards indoors). All VIPs used in the study were composed of fumed silica core material encapsulated in a tri-metalized laminate envelope. IR thermography assessments proved that VIPs had been properly integrated in the system, with no defects or failure. During daytime, on a representative winter day (5th February 2020), the maximum temperatures $\left(T_{\max }\right)$ at the spandrel-frame thermal bridge junction were $2.3{ }^{\circ} \mathrm{C}, 1.2{ }^{\circ} \mathrm{C}$, and $0.6{ }^{\circ} \mathrm{C}$ higher than the $\mathrm{T}_{\max }$ at the center of the spandrel for Case 1, Case 2, and Case 3, respectively. During the night, the minimum temperatures $\left(\mathrm{T}_{\min }\right)$ at the spandrel-frame thermal bridge junction were $2{ }^{\circ} \mathrm{C}, 1.2{ }^{\circ} \mathrm{C}$, and $1{ }^{\circ} \mathrm{C}$ lower than the $\mathrm{T}_{\min }$ at the center of the spandrel for Case 1 , Case 2, and Case 3, respectively. Thus, the thermal bridge effect of the aluminum frame had the least effect on Case 3. This also indicates that the existence of thermal bridges, caused by the framing element, cannot be marginalized. Although the thermal characteristics of Case 2 was slightly comparable to Case 3, the latter showed the strongest resistance against surface condensation and the lowest thermal bridge effect at the spandrel-Al frame junctions, as well as the lowest heat losses or gains. This is particularly due to the Case 3 VIP spandrel's unique configuration, boosted by a double-layer VIP configuration together with an additional covering of a thin XPS layer.

Considering the technical space constraints related to the insulation of slim curtain wall spandrel systems, a VIP is a viable mode of insulation for a curtain wall spandrel due to its high thermal resistance per unit thickness compared to any other kind of insulation currently available. Therefore, the integration of VIPs as insulation for curtain wall spandrels can be seen as a tenable solution. Future research efforts on the subject could focus on investigating the energy performance and economic payback of bigger sized VIP spandrels in large-scale occupied curtain walled constructions. Finally, noteworthy limitations of experimental methods employed and future perspectives were discussed. This study will be interesting and provide new knowledge to building researchers, scientists and engineers, and general stakeholders in the building industry.

Author Contributions: Conceptualization, F.E.B., J.-T.K. and J.-H.K.; methodology, F.E.B. and J.-T.K.; software, F.E.B. and S.-M.K.; validation, F.E.B., J.-H.K. and J.-G.A.; formal analysis, F.E.B., J.-G.A. and S.-M.K.; investigation, F.E.B. and S.-M.K.; data curation, F.E.B.; writing-original draft preparation, F.E.B.; writing-review and editing, F.E.B., J.-H.K. and J.-T.K.; visualization, F.E.B. and J.-G.A.; supervision, J.-T.K.; project administration, J.-H.K.; funding acquisition, J.-T.K. All authors have read and agreed to the published version of the manuscript. 
Funding: This work was supported by the National Research Foundation (NRF), funded by the Ministry of Science and ICT (MIST) of the Republic of Korea (NRF-2021R1A2C2092760), and also funded by the National University Development Project by the Ministry of Education in 2020.

Institutional Review Board Statement: Not applicable.

Informed Consent Statement: Not applicable.

Data Availability Statement: The data presented in this study is available on request by contacting the corresponding author.

Acknowledgments: The authors appreciate the discussion contributions of Samuel Brunner of EMPA.

Conflicts of Interest: The authors declare no conflict of interest.

\section{References}

1. International Energy Agency (IEA). Tracking Buildings 2020. Available online: https://www.iea.org/reports/tracking-buildings2020 (accessed on 3 March 2021).

2. Smith, R.E.; Timberlake, J. Prefab Architecture: A Guide to Modular Design and Construction; John Wiley \& Sons: Hoboken, NJ, USA, 2011

3. Rizzo, F.; Franco, A.; Bonati, A.; Maddaloni, G.; Caterino, N.; Occhiuzzi, A. Predictive analyses for aerodynamic investigation of curtain walls. Structures 2021, 29, 1059-1077. [CrossRef]

4. Ge, H. Study on Overall Thermal Performance of Metal Curtain Walls. Ph.D. Thesis, Concordia University, Montreal, QC, Canada, 2002.

5. $\quad$ Sanders, R.M. Curtain walls: Not just another pretty facade. J. Archit. Technol. 2006, 23, 1-8.

6. Kazmierczak, K.; Hershfi, M. Review of Curtain Walls, Focusing on Design Problems and Solutions. In Proceedings of the Building Enclosure Science and Technology (BEST2) Conference, Portland, OR, USA, 15-18 April 2010.

7. Bedon, C.; Amadio, C.; Noé, S. Safety issues in the seismic design of secondary frameless glass structures. Safety 2019, 5, 80. [CrossRef]

8. Huang, B.; Chen, S.; Lu, W.; Mosalam, K.M. Seismic demand and experimental evaluation of the nonstructural building curtain wall: A review. Soil Dyn. Earthq. Eng. 2017, 100, 16-33. [CrossRef]

9. Mojškerc, B.; Kek, T.; Grum, J. Pulse-Echo Ultrasonic Testing of Adhesively Bonded Joints in Glass Façades. Stroj. Vesn. J. Mech. Eng. 2016, 62, 147-153. [CrossRef]

10. Lin, J.; Hong, X.; Ren, Z. Laser in-depth heating thermal wave detection of adhesive debonding in glass curtain walls: Numerical simulation and experiment. Measurement 2021, 177, 109268. [CrossRef]

11. Teng-teng, H.; Da-Wei, Z.; Yu-xi, Z.; Jun-jin, L.; Jian-hui, L. Comprehensive appraisal of the safety of hidden frame glass curtain wall based on fuzzy theory. J. Build. Eng. 2019, 26, 100863. [CrossRef]

12. Kim, T.; Kim, Y.-W.; Cho, H. A simulation-based dynamic scheduling model for curtain wall production considering construction planning reliability. J. Clean. Prod. 2021, 286, 124922. [CrossRef]

13. Bedon, C.; Zhang, X.; Santos, F.; Honfi, D.; Kozłowski, M.; Arrigoni, M.; Figuli, L.; Lange, D. Performance of structural glass facades under extreme loads-Design methods, existing research, current issues and trends. Constr. Build. Mater. 2018, 163, 921-937. [CrossRef]

14. Wang, Y.; Xie, Q.; Zhang, Y.; Wang, Q.; Sun, J. Sensitivity analysis of influencing factors on glass façade breakage in fire. Fire Saf. J. 2018, 98, 38-47. [CrossRef]

15. Ma, X.; Tu, R.; An, W.; Xu, L.; Luo, S.; Wang, J.; Tang, F. Experimental study of interlayer effect induced by building facade curtain wall on downward flame spread behavior of polyurethane. Appl. Therm. Eng. 2020, 167, 114694. [CrossRef]

16. Lam, T.; Ge, H.; Fazio, P. Impact of curtain wall configurations on building energy performance in the perimeter zone for a cold climate. Energy Procedia 2015, 78, 352-357. [CrossRef]

17. Bouden, C. Influence of glass curtain walls on the building thermal energy consumption under Tunisian climatic conditions: The case of administrative buildings. Renew. Energy 2007, 32, 141-156. [CrossRef]

18. Lam, T.C.A. Identifying Configurations of Plus-Energy Curtain Walls for the Perimeter Zone Using the Analysis of Variance (ANOVA) Approach. Master's Thesis, Concordia University, Montreal, QC, Canada, 2015.

19. Carbary, L.; Dunlap, A.; O'Connor, T. High performance curtain wall using vacuum insulated panels (VIP) spandrels. In Proceedings of the Glass Performance Days Conference, Tampere, Finland, 13-15 June 2013.

20. Carbary, L.D.; Stanley, Y.; Nick, B. Architectural insulation modules: Thermal and structural performance for use in curtainwall construction. In Proceedings of the International Conference on Building Envelope Systems and Technologies ICBEST, Aachen, Germany, 9-12 June 2014.

21. Richman, R.; Pressnail, K. A more sustainable curtain wall system: Analytical modeling of the solar dynamic buffer zone (SDBZ) curtain wall. Build. Environ. 2009, 44, 1-10. [CrossRef]

22. Behr, R.A. On-site investigations of spandrel glass microenvironments. Build. Environ. 1995, 30, 61-72. [CrossRef] 
23. Lam, T.C.; Ge, H.; Fazio, P. Study of different glazing modelling approaches in assessing energy performance of curtain wall systems using EnergyPlus. In Proceedings of the International Building Performance Simulation Association (IBPSA) eSIM Conference, Ottawa, ON, Canada, 29 June 2014.

24. Kim, G.; Lim, H.S.; Schaefer, L.; Kim, J.T. Overall environmental modelling of newly designed curtain wall facade configurations. Indoor Built Environ. 2012, 22, 168-179. [CrossRef]

25. Arnesano, M.; Pandarese, G.; Martarelli, M.; Naspi, F.; Gurunatha, K.L.; Sol, C.; Portnoi, M.; Ramirez, F.V.; Parkin, I.P.; Papakonstantinou, I.; et al. Optimization of the thermochromic glazing design for curtain wall buildings based on experimental measurements and dynamic simulation. Sol. Energy 2021, 216, 14-25. [CrossRef]

26. Goia, F. Search for the optimal window-to-wall ratio in office buildings in different European climates and the implications on total energy saving potential. Sol. Energy 2016, 132, 467-492. [CrossRef]

27. Poirazis, H.; Blomsterberg, Å.; Wall, M. Energy simulations for glazed office buildings in Sweden. Energy Build. 2008, 40, 1161-1170. [CrossRef]

28. Mainini, A.G.; Poli, T.; Zinzi, M.; Speroni, A. Metal mesh as shading devices and thermal response of an office building: Parametric analysis. Energy Procedia 2015, 78, 103-109. [CrossRef]

29. Qian, Z.-Y.; Zhao, Y.-Z.; Fu, Z.; Cao, Q.-X. Design and realization of a non-actuated glass-curtain wall-cleaning robot prototype with dual suction cups. Int. J. Adv. Manuf. Technol. 2006, 30, 147-155. [CrossRef]

30. Jelle, B.P.; Hynd, A.; Gustavsen, A.; Arasteh, D.; Goudey, H.; Hart, R. Fenestration of today and tomorrow: A state-of-the-art review and future research opportunities. Sol. Energy Mater. Sol. Cells 2012, 96, 1-28. [CrossRef]

31. Yu, F.; Wennersten, R.; Leng, J. A state-of-art review on concepts, criteria, methods and factors for reaching 'thermal-daylighting balance'. Build. Environ. 2020, 186, 107330. [CrossRef]

32. Cuce, E.; Riffat, S.B. A state-of-the-art review on innovative glazing technologies. Renew. Sustain. Energy Rev. 2015, 41, 695-714. [CrossRef]

33. Buratti, C.; Belloni, E.; Merli, F.; Zinzi, M. Aerogel Glazing Systems for Building Applications: A Review. Energy Build. 2020, 231, 110587. [CrossRef]

34. Boafo, F.E.; Kim, J.-H.; Kim, J.-T. Numerical study of slim curtain wall spandrel with integrated vacuum insulation panel: Concept, performance evaluation and challenges. Energy Build. 2019, 183, 139-150. [CrossRef]

35. Postole, R.; Roppel, P.; Norris, N.; Bigdeli, K. Performance of sealed curtain wall spandrel panels that direct sunlight deep into multi-story buildings. In Proceedings of the 4th Building Enclosure Science and Technology (BEST4) Conference, Kansas City, KS, USA, 13-15 April 2015.

36. Binz, A.; Moosmann, A.; Steinke, G.; Schonhardt, U.; Fregnan, F.; Simmler, H.; Brunner, S.; Ghazi, K.; Bundi, R.; Heinemann, U.; et al. HiPTI-High Performance Thermal Insulation, Annex 39 to IEA/ECBCS-Implementing Agreement. Vacuum Insulation in the Building Sector. Systems and Applications; International Energy Agency: Paris, France, 2005; Available online: https: //www.iea-ebc.org/projects / project?AnnexID=39 (accessed on 26 March 2021).

37. Adl-Zarrabi, B.; Quenard, D.; Johansson, P.; Heinemann, U.; Yrieix, B.; Sprengard, C.; Heinemann, U.; Mukhopadhyaya, P.; Brunner, S.; Galliano, R.; et al. Annex 65-Long Term Performance of Super-Insulating Materials in Building Components and Systems, Subtask III-Practical Applications Retrofitting at the Building Scale, Final Report; International Energy Agency: Paris, France, 2020; Available online: https:/ / www.iea-ebc.org/projects/project?AnnexID=65 (accessed on 21 September 2020).

38. Kalnæs, S.E.; Jelle, B.P. Vacuum insulation panel products: A state-of-the-art review and future research pathways. Appl. Energy 2014, 116, 355-375. [CrossRef]

39. Brunner, S.; Wakili, K.G.; Stahl, T.; Binder, B. Vacuum insulation panels for building applications-Continuous challenges and developments. Energy Build. 2014, 85, 592-596. [CrossRef]

40. Schiavoni, S.; Bianchi, F.; Asdrubali, F. Insulation materials for the building sector: A review and comparative analysis. Renew. Sustain. Energy Rev. 2016, 62, 988-1011. [CrossRef]

41. Batard, A.; Duforestel, T.; Flandin, L.; Yrieix, B. Prediction method of the long-term thermal performance of Vacuum Insulation Panels installed in building thermal insulation applications. Energy Build. 2018, 178, 1-10. [CrossRef]

42. Berardi, U.; Nikafkar, M.; Wi, S.; Kim, S. Experimental verification of the theoretical aging of vacuum insulated panels. J. Ind. Eng. Chem. 2020, 90, 300-304. [CrossRef]

43. Fantucci, S.; Garbaccio, S.; Lorenzati, A.; Perino, M. Thermo-economic analysis of building energy retrofits using VIP-Vacuum Insulation Panels. Energy Build. 2019, 196, 269-279. [CrossRef]

44. Baetens, R.; Jelle, B.P.; Thue, J.V.; Tenpierik, M.J.; Grynning, S.; Uvsløkk, S.; Gustavsen, A. Vacuum insulation panels for building applications: A review and beyond. Energy Build. 2010, 42, 147-172. [CrossRef]

45. Gubbels, F.; Santi, D.D.; Baily, V. Durability of vacuum insulation panels in the cavity of an insulating glass unit. J. Build. Phys. 2015, 38, 485-499. [CrossRef]

46. Boafo, F.E.; Kim, J.-H.; Ahn, J.-G.; Kim, S.-M.; Kim, J.-T. Slim curtain wall spandrel integrated with vacuum insulation panel: A state-of-the-art review and future opportunities. J. Build. Eng. 2021, 42, 102445. [CrossRef]

47. Brunner, S.; Tharian, P.; Simmler, H.; Ghazi Wakili, K. Focused ion beam (FIB) etching to investigate aluminium-coated polymer laminates subjected to heat and moisture loads. Surf. Coat. Technol. 2008, 202, 6054-6063. [CrossRef] 
48. Avery Dennison Hanita Ltd. Metalized Malinated for Vacuum Insulation Panels (V08621B). Available online: https: //hanita.averydennison.com/content/dam/averydennison/hanita/en/docs/home/customer-tools/vip-lam/long-verylong/pds-vip-v08621b-trilaminate.pdf (accessed on 2 October 2019).

49. Kim, J.-H.; Boafo, F.E.; Kim, S.-M.; Kim, J.-T. Aging performance evaluation of vacuum insulation panel (VIP). Case Stud. Constr. Mater. 2017, 7, 329-335. [CrossRef]

50. Physibel BISCO Manual. Computer Program to Calculate 2D Steady State Heat Transfer in Free-Form Objects, Version 10.0w; Physibel: Ghent, Belgium, 2012.

51. Physibel TRISCO Manual. Computer Program to Calculate 3D \& 2D Steady State Heat Transfer in Rectangular Objects, Version 13.0w; Physibel: Ghent, Belgium, 2015.

52. Wakili, K.G.; Bundi, R.; Binder, B. Effective thermal conductivity of vacuum insulation panels. Build. Res. Inf. 2004, 32, 293-299. [CrossRef]

53. Park, S.; Choi, B.-H.; Lim, J.-H.; Song, S.-Y. Evaluation of Mechanically and Adhesively Fixed External Insulation Systems Using Vacuum Insulation Panels for High-Rise Apartment Buildings. Energies 2014, 7, 5764-5786. [CrossRef]

54. Isaia, F.; Fantucci, S.; Capozzoli, A.; Perino, M. Vacuum Insulation Panels: Thermal bridging effects and energy performance in real building applications. Energy Procedia 2015, 83, 269-278. [CrossRef]

55. Lorenzati, A.; Fantucci, S.; Capozzoli, A.; Perino, M. The effect of different materials joint in Vacuum Insulation Panels. Energy Procedia 2014, 62, 374-381. [CrossRef]

56. Lorenzati, A.; Fantucci, S.; Capozzoli, A.; Perino, M. Experimental and numerical investigation of thermal bridging effects of jointed Vacuum Insulation Panels. Energy Build. 2016, 111, 164-175. [CrossRef]

57. Nussbaumer, T.; Bundi, R.; Tanner, C.; Muehlebach, H. Thermal analysis of a wooden door system with integrated vacuum insulation panels. Energy Build. 2005, 37, 1107-1113. [CrossRef]

58. Tenpierik, M.; Cauberg, H. Analytical models for calculating thermal bridge effects caused by thin high barrier envelopes around vacuum insulation panels. J. Build. Phys. 2007, 30, 185-215. [CrossRef]

59. Kim, S.-M.; Kim, J.-H.; Kim, J.-T. Effect of thermal bridge on the insulation performance of VIP applied walls. In Proceedings of the 6th ZEMCH International Conference, Melbourne, Australia, 29 January-5 February 2018.

60. Song, J.-H.; Lim, J.-H.; Song, S.-Y. Evaluation of alternatives for reducing thermal bridges in metal panel curtain wall systems. Energy Build. 2016, 127, 138-158. [CrossRef]

61. Ministry of Land, Infrastructure and Transport (MOLIT) \& Korea Energy Agency (KEA). Building Energy Saving Design Guideline. Available online: https:/ / www.energy.or.kr/web/kem_home_new/new_main.asp (accessed on 7 November 2018).

62. ISO 10456:2007; Building Materials and Products-Hygrothermal Properties-Tabulated Design Values and Procedures for Determining Declared and Design Thermal Values. International Organization Standardization: Geneva, Switzerland, 2007.

63. Mukhopadhyaya, P.; MacLean, D.; Korn, J.; van Reenen, D.; Molleti, S. Building application and thermal performance of vacuum insulation panels (VIPs) in Canadian subarctic climate. Energy Build. 2014, 85, 672-680. [CrossRef]

64. Johansson, P.; Adl-Zarrabi, B.; Kalagasidis, A.S. Evaluation of 5 years' performance of VIPs in a retrofitted building façade. Energy Build. 2016, 130, 488-494. [CrossRef]

65. Boafo, F.E.; Chen, Z.; Li, C.; Li, B.; Xu, T. Structure of vacuum insulation panel in building system. Energy Build. 2014, 85, 644-653 [CrossRef]

66. Brunner, S.; Simmler, H. In situ performance assessment of vacuum insulation panels in a flat roof construction. Vacuum 2008, 82, 700-707. [CrossRef]

67. Voellinger, T.; Bassi, A.; Heitel, M. Facilitating the incorporation of VIP into precast concrete sandwich panels. Energy Build. 2014, 85, 666-671. [CrossRef]

68. Molleti, S.; Mukhopadyaya, P.; Baskaran, B.; Beaulieu, P.; Sherrer, G. Application of VIPs on low sloped commercial roofing systems. In Proceedings of the 10th International Vacuum Insulation Symposium, Ottawa, ON, Canada, 15-16 September 2011.

69. The 3M Company. 3M ${ }^{\mathrm{TM}}$ Sun Control Window Film Traditional Series. Available online: https://www.3m.com/3M/en_US/p/ d/b00016656/ (accessed on 15 December 2021).

70. ISO 10211:2007; Thermal Bridges in Building Construction-Heat Flows and Surface Temperatures-Detailed Calculations. International Organization for Standardization: Geneva, Switzerland, 2007.

71. Kalamees, T. Critical values for the temperature factor to assess thermal bridges. In Proceedings of the Estonian Academy of Sciences: Engineering; Aben, H., Kurnitski, V., Eds.; Estonian Academy Publishers: Tallinn, Estonia, 2006; pp. 218-229.

72. Brunner, S.; Stahl, T.; Ghazi Wakili, K. Double layered vacuum insulation panels. In Proceedings of the 3rd Building Enclosure Science and Technology (BEST3) Conference, Atlanta, GA, USA, 2-4 April 2012. 